\title{
Adaptive Responses to Nitrogen and Light Supplies of a Local Varieties of Sweet Pepper from the Abruzzo Region, Southern Italy
}

\author{
Fabio Stagnari ${ }^{1}$, Gabriele Campanelli ${ }^{2}{ }^{\mathbb{D}}$, Angelica Galieni ${ }^{2, *}$, Cristiano Platani ${ }^{2}$, Aldo Bertone ${ }^{2}$ \\ and Nadia Ficcadenti ${ }^{2}$ \\ 1 Faculty of Bioscience and Technology for Agriculture Food and Environment, \\ Campus Universitario di Coste Sant'Agostino, University of Teramo, Via R. Balzarini 1, 64100 Teramo, Italy; \\ fstagnari@unite.it \\ 2 Research Centre for Vegetable and Ornamental Crops, Council for Agricultural Research and Economics-CREA, \\ Via Salaria 1, 63077 Monsampolo del Tronto, Italy; gabriele.campanelli@crea.gov.it (G.C.); \\ cristiano.platani@crea.gov.it (C.P.); aldo.bertone@crea.gov.it (A.B.); nadia.ficcadenti@crea.gov.it (N.F.) \\ * Correspondence: angelica.galieni@crea.gov.it
}

\section{check for} updates

Citation: Stagnari, F.; Campanelli, G. Galieni, A.; Platani, C.; Bertone, A.; Ficcadenti, N. Adaptive Responses to Nitrogen and Light Supplies of a Local Varieties of Sweet Pepper from the Abruzzo Region, Southern Italy. Agronomy 2021, 11, 1343. https:/ / doi.org/10.3390/agronomy11071343

Academic Editors: Aspasia (Sissy)

P. Efthimiadou and

Nikolaos Katsenios

Received: 31 May 2021

Accepted: 28 June 2021

Published: 30 June 2021

Publisher's Note: MDPI stays neutral with regard to jurisdictional claims in published maps and institutional affiliations.

Copyright: (c) 2021 by the authors. Licensee MDPI, Basel, Switzerland. This article is an open access article distributed under the terms and conditions of the Creative Commons Attribution (CC BY) license (https:// creativecommons.org/licenses/by/ $4.0 /)$.

\begin{abstract}
Local varieties represent a heritage for plant biodiversity and, thanks to their resilience, are characterized by a better adaptation and rusticity to environmental variables. This work reports the morphological and physiological responses of a local ecotype of sweet pepper grown in Southern Italy, i.e., Altino, to $\mathrm{N}$ and light supplied at optimal and sub-optimal levels. In 2017, two openfield experiments were set up, comparing increasing $\mathrm{N}$ rates $\left(0,100\right.$ and $200 \mathrm{~kg} \mathrm{~N}^{-1}$, 0_N, 100_N and 200_N, respectively) and different percentages of shading and/or manipulations of the transmitted solar radiation, obtained through photoselective nets (red net, RN; black net, BN; unshaded Control). The unfertilized plants reduced growth (by $32 \%$ on average, at 83 days after transplanting, DAT), especially in terms of number of leaves, leaf area and effectiveness (chlorophyll content) of photosynthetic apparatus; no differences were recorded among fertilization treatments. On the other hand, the shading avoidance mechanisms resulted in higher biomass partitioned to leaves at the expense of sink organs, the building of more expanse (higher total leaf area) and thinner (higher specific leaf area and lower leaf-cuticular waxes) photosynthetic apparatus, and in a greater concentration of leaf pigments. The effects on yield and fruit quality of Altino ecotype deserve to be further explored.
\end{abstract}

Keywords: N management; light-availability; pepper; Altino ecotype; source-sink relations; photoselective nets; plant's avoidance and tolerance mechanisms

\section{Introduction}

Capsicum annuum $\mathrm{L}$. is one of the most cultivated and economically important vegetable species worldwide, being widespread on an area that exceeds 1.5 million hectares, including both spicy and sweet peppers [1-3]. The latter is mainly cultivated in the Mediterranean Basin where Italy represents one of the most important countries in the world, especially in south Regions [3].

Moreover, Italy, due to its geographical and historical compliance, includes a significant richness of cultivated biodiversity and landraces, which are important genetic reservoirs of useful genes. Among sweet pepper genotypes, the Altino ecotype is a typical niche of the horticultural product of the Abruzzo region (Southern Italy), and it is included in the traditional list of local products; fruits are harvested at maturity (red) and left to air-dry to obtain a powder to be used in many typical culinary dishes.

As a local variety, the Altino ecotype is characterized by good adaptation and rusticity and is prone to sustainable cultivation systems under low-input conditions [4], e.g., reduced 
the total use of agricultural chemicals, especially nitrogen $(\mathrm{N})$ fertilization. In any case, $\mathrm{N}$ management must be calibrated based on the critical $\mathrm{N}$ curve and the $\mathrm{N}$ use efficiency to reduce $\mathrm{N}$ losses and environmental pollution [5]. Moreover, such ecotype could take advantage of some crop protection practices, such as the use of photoselective nets, finding a valid justification in the high added value of local productions (i.e., DOP, IGP, Slow Food praesidium). Netting, besides a significant improvement in terms of yield and postharvest quality of many horticultural crops [6-8]—including sweet pepper [9]—can induce a moderate cooling effect useful in pest control [10] as well as protect fruits from sunburn damages [11] in prone vegetables, such as Altino ecotype.

In general, studies on the response of local varieties to agronomic techniques and environmental conditions are missing. Besides, it is essential to understand the mechanisms of adaptation of such genotypes both to support plant breeding for high-quality products and agronomic management under low-input environments, as well as to increase farming systems diffusion in marginal areas. $\mathrm{N}$ availability and the amount of photosynthetically active radiation (PAR) transmitted to the canopy are two of the major determinants affecting plant morphological, anatomical, and physiological responses. Nitrogen is, indeed, essential for normal growth and development, being an integral part of protein development and chloroplast structure [12]. Under low-N conditions, a decrease in $\mathrm{C}$ assimilation, resulting in a consequent decrease in the mesophyll cell surface area per unit leaf area, is observed [13]. Moreover, plants grown under low-light environments are taken to invest more biomass in leaves, at the expense of roots, to access the most limiting factor, i.e., radiation [14].

Taken into account such considerations, our study was based on the following assumptions: (i) $\mathrm{N}$ and light supply are the major determinants in crop growth and development; (ii) such growth factors can be easily modulated in open-field by manipulating agronomic practices under low-input systems to enhance yield and quality (harvest and post-harvest) of local productions; (iii) the study of plant responses to the growth environment is specieand genotype-specific; and (iv) local varieties are among the less studied ones in terms of adaptive response to both environment and agronomic techniques.

Therefore, the objective of this study was to evaluate both the separate and combinate effects of light and $\mathrm{N}$ supplied at optimal and suboptimal levels, on growth, morphological, and physiological responses of Altino ecotype plants. To reduce the experimental error coming from the normal genetic variation occurring within the local population, the collection of Altino ecotype was previously subjected to 2 cycles of selection and selffertilization, as is fully described in the Section 2.

\section{Materials and Methods}

\subsection{Plant Materials}

Seeds of red sweet pepper Capsicum annuum L. ecotype "Altino" were provided in 2015 by a keeper farmer located at Altino $(\mathrm{CH})$, in the Abruzzo region (Central Italy). Despite pepper is considered an autogamous species, it can attract insects, and allogamy can reach up to $40 \%$ to $100 \%$ under favourable conditions [15]. As a consequence, the collection was initially characterized for its uniformity in terms of growth habitus, yield aptitude as well as fruits shape and size, and subjected to two cycles of phenotypic selection (2015 and 2016), purging phenotypes carrying "off-specific" traits, as detailed below.

During the first year, pepper plants-grown at the experimental field of the Research Centre for Vegetable and Ornamental Crops, Council for Agricultural Research and Economics (CREA-OF), located in Monsampolo del Tronto (AP) (latitude $42^{\circ} 52^{\prime} 59.1^{\prime \prime} \mathrm{N}$, longitude $13^{\circ} 48^{\prime} 01.9^{\prime \prime} \mathrm{E}$ ), in the coastal area of the Marche Region (Central Italy) from May to September 2015-was cultivated in an experimental field of $1600 \mathrm{~m}^{2}$. The crop was managed according to the typical pepper cultivation techniques; plants were grown in twin-rows with a spacing of $0.4 \mathrm{~m}$ between plants and rows, and $0.8 \mathrm{~m}$ between twin-rows. Plastic mulching was applied into the twin-rows, while a mechanical weeds control was performed between twin rows. Phenotypes (plants) were selected based on the keeper 
farmers' local knowledge and the defective ones were excluded from the selection. Plants corresponding to the ideotype were self-fertilized under a net isolator and seeds were collected for the second phenotypic' selection cycle, performed in 2016 in a second experimental field at the CREA-OF. Eleven pepper phenotypes were cultivated in about $10 \mathrm{~m} \times 13 \mathrm{~m}$ plots, following the agronomic practices adopted in the previous year. As in 2015 , the phenotypes (plants) corresponding to the ideotype (in terms of both plant and fruits morphological traits) were marked and self-fertilized to obtain pure seeds to be used in the "agronomic" experiments (see Sections 2.2 and 2.3), carried out in 2017. As early as the second generation of self-fertilization was sufficiently stable for the typical characters indicated for the ideotype and two phenotypes (named as 97 and 99, see Figure S1), characterized by analogues and uniform morphological traits, were selected; the main measured morphological characteristics (weight, diameter, and length of the fruits when ripe) are shown in Table S1.

\subsection{Site Description}

In 2017 (from 15 May to 22 September), two experiments (named as Exp_1 and Exp_2) were carried out at the experimental fields of the CREA-OF (Monsampolo del Tronto), using seeds of the two phenotypes 97 and 99, for Exp_1 and Exp_2, respectively.

The location is characterized by a typical thermal-mediterranean climate, with winter temperatures that can fall below $0{ }^{\circ} \mathrm{C}$, and summer temperatures that can rise above $40{ }^{\circ} \mathrm{C}$. The rainfall is mainly concentrated between October and April. During the experimental period, meteorological data were recorded by a meteorological station situated $\sim 600 \mathrm{~m}$ from the experimental field. The average temperature over the crop growing cycle was $22.0^{\circ} \mathrm{C}$, with peaks of $38.1^{\circ} \mathrm{C}$ in the first decade of August; during the May-September period, the crop received $95.8 \mathrm{~mm}$ of rain.

Pepper was grown on soil previously hosting artichoke, with the main characteristics: $392 \mathrm{~g} \mathrm{~kg}^{-1}$ sand, $367 \mathrm{~g} \mathrm{~kg}^{-1}$ silt, $241 \mathrm{~g} \mathrm{~kg}^{-1}$ clay, $1.50 \%$ organic matter, and $0.80 \mathrm{~g} \mathrm{~kg}^{-1}$ total $\mathrm{N}$ (soil $\mathrm{NO}_{3}-\mathrm{N}$ and $\mathrm{NH}_{4}-\mathrm{N}=11.90$ and $1.36 \mathrm{mg} \mathrm{kg}^{-1}$, respectively).

\subsection{Experiments Description and Growing Conditions}

In both Exp_1 and Exp_2, pepper seeds were sown on 15 May 2017 in a nursery substrate and maintained in the greenhouse, under controlled conditions. Plants were transplanted on 6 June 2017, as 22-days-old seedlings (4 leaf stage), in the open field in twin-rows with a spacing of $0.4 \mathrm{~m}$ between plants and rows, and $1.6 \mathrm{~m}$ between twin-rows. The distance between twin-rows was justified to ensure compliance with a sufficient edge area between experimental treatments, as detailed reported below.

Both experiments were arranged as a split-plot design with three replications, comparing three nitrogen fertilization rates (main treatment) and three shade conditions (secondary treatment), for a total of nine experimental treatments obtained from the $\mathrm{N} \times$ Shade combinations.

The main treatments were established in an experimental area of about $17.4 \mathrm{~m}^{2}$ each, including a single pepper twin row and a total of 72 pepper plants. The three $\mathrm{N}$ fertilization rates consisted in a 0,100 and $200 \mathrm{~kg} \mathrm{~N} \mathrm{ha}^{-1}$ nutrition (named 0_N, 100_N and 200_N, respectively), obtained by applying Urea at 9 days after transplanting (DAT).

For each $\mathrm{N}$ treatments, subplots were obtained by splitting the total area in three subplots of $4.8 \mathrm{~m}^{2}$ (20 pepper plants; Figure S2). Shading conditions were accomplished using different coloured shading nets (Sh treatments: red net, RN; black net, BN) in addition to an unshaded control (Control), wrapped around $1.7 \mathrm{~m}$-height tunnels, placed over the crop. To allow air circulation on the hottest days, tunnels were open at both ends. Each subplot consisted of a total of 20 pepper plants, grown in a single twin-row. Red and Black nets were provided by Agrintech S.r.l. (Iridium ${ }^{\circledR}$ Rosso and Monotex 30, respectively; Eboli, SA, Italy); the main environmental characteristics recorded under $\mathrm{RN}$ and $\mathrm{BN}$ with respect to Control are reported in Table S2.

Photosynthetically Active Radiation (PAR) intensity was measured with a PAR Photon Flux Sensor (Decagon Devices Inc., Pullman, WA, USA) placed above the vegetation 
and connected to a data logger (EM50 Data Collection System, Decagon Devices Inc., Pullman, WA, USA), at 15-min intervals starting from 9 DAT, till to crop harvest; the irradiance daily quantum input (DQI, $\mathrm{mol} \mathrm{m}^{-2}$ ), as recorded during the pepper cycle, was reported in Figure 1A. The amount of shading (\%) was determined by comparing the daily average PAR values of nets with the daily average PAR values of the Control treatment. Following Shahak et al. [16], the amount of scattered light in the PAR region was measured at noontime of clear days using an opaque disc, held to $30-40 \mathrm{~cm}$ above the PAR sensor and its percentage was then calculated as the ratio between not-direct light to total light. To obtain information about the absorbed and transmitted radiation by photo-selective nets, radiance under coloured films was measured with the HandHeld 2 Pro Portable Spectroradiometer (FieldSpec, ADS Inc., Boulder, CO, USA), which measures radiation in the visible and near-infrared (NIR) wavelengths from 325 to $1075 \mathrm{~nm}( \pm 2 \mathrm{~nm})$, using a reflective surface characterized by a certificated reflectivity of $99 \%$. Measurements were taken, at noontime and within a few minutes of sunny days during the middle phases of the crop cycles, with (shaded treatments) and without (Control) coloured nets; relative radiance (as a mean value of four measurements, two for Exp_1 and two for Exp_2) of RN and $\mathrm{BN}$ with respect to Control is reported in Figure 1B.

(A)

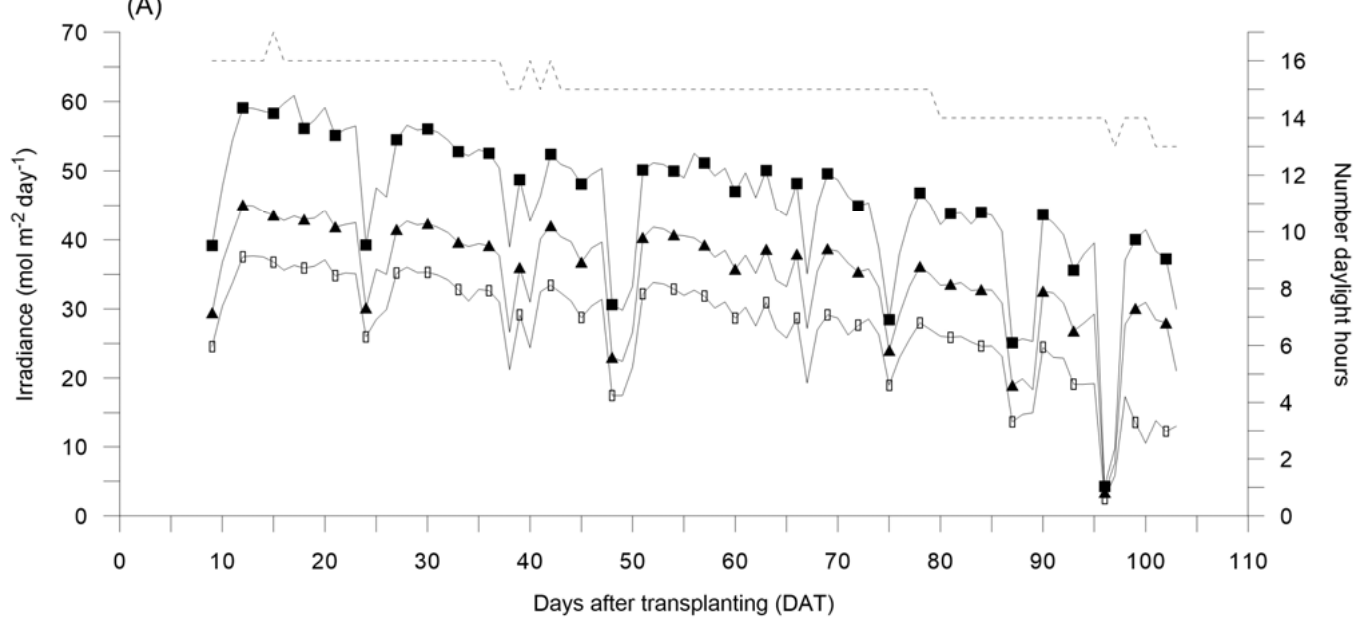

(B)

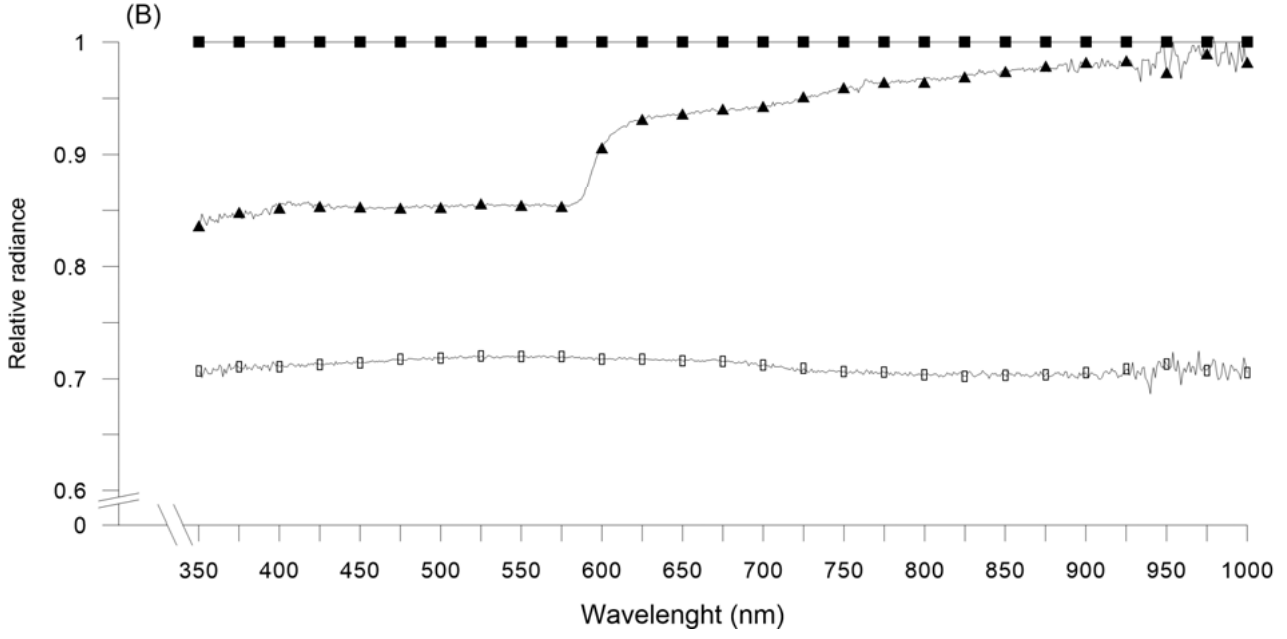

Figure 1. (A) Irradiance daily quantum input $\left(\mathrm{mol} \mathrm{m}^{-2} \mathrm{day}^{-1}\right)$ as observed under red (RN) and black (BN) photo-selective nets with respect to unshaded control (Control), starting form 9 days after bell pepper transplanting (DAT), in 2017; dashed line indicates the number of daylight hours during pepper growing cycle. (B) Relative radiance as observed under RN and BN with respect to Control, in 2017. Control: black squares; RN: black triangles; BN: black circles. 
Relative humidity and air temperatures under coloured nets were recorded by sensors of temperature and humidity connected to a data logger system (EM50 Data Collection System, Decagon Devices Inc., Pullman, WA, USA) (Table S2).

The fixed sensors for the in-continuum measurements of the environmental parameters under photo-selective nets were placed only in Exp_1, considering the use of the samecoloured nets among the two experiments.

Crop was fertilized with potassium and phosphorus during soil preparation, at the rate of 80 and $150 \mathrm{~kg}^{-1}$ of $\mathrm{P}_{2} \mathrm{O}_{5}$ and $\mathrm{K}_{2} \mathrm{O}$, respectively. Black plastic mulch and the drip irrigation plastic tubing were placed on pepper twin-rows. Weeds were mechanically and manually controlled between twin-rows and on the rows, respectively. No insecticide treatment was carried out; when necessary, fungal diseases were treated with CUPROXAT ${ }^{\circledR}$ SDI (Nufarm Italy, Milano, Italy), at the dose of $2 \mathrm{~L} \mathrm{ha}^{-1}$.

\subsection{Growth Analysis, Morphological Traits, and N Determinations}

In both Exp_1 and Exp_2 two plants per experimental unit (each sub-plot of 20 plants) were sampled at 21, 42 and 83 DAT. Sampled plants were separated into leaves, stems and reproductive organs (flowers at 21 DAT; flowers and green fruits at 42 DAT; green, ripening and red fruits at $83 \mathrm{DAT}$ ) dried with an oven at $70{ }^{\circ} \mathrm{C}$, until constant weight (DW determination). Before drying, stem length $(\mathrm{cm})$, stem diameter $(\mathrm{mm})$, and number of leaves (num) was measured; leaf area $\left(\mathrm{LA}, \mathrm{cm}^{2}\right.$ ) was recorded after acquiring scanned leaves' images with an image analysis software (ImageJ, National Institutes of Health, Bethesda, MD, USA). The specific leaf area (SLA, $\mathrm{cm}^{2} \mathrm{~g}^{-1}$ ) was then calculated.

Starting from organs DWs, leaf mass ratio (LMR), stem mass ratio (SMR) and reproductive organs mass ratio (RMR) were calculated as the ratios between leaf, stems and reproductive organs (flowers/fruits) to total DW, respectively.

Relative growth rate (RGR $\mathrm{g} \mathrm{g}^{-1} \mathrm{DAT}$ ) was estimated applying the following equation:

$$
\mathrm{RGR}=\frac{\left(\ln \mathrm{M}_{\mathrm{t}}-\ln \mathrm{M}_{\mathrm{t}-1}\right)}{(\mathrm{t}-\mathrm{t}-1)}
$$

where $M_{t}$ and $M_{t-1}$ represent the total dry biomass at time $t$ and $t-1$, respectively.

The leaf area ratio (LAR, $\mathrm{cm}^{2} \mathrm{~g}^{-1}$ ), that is the amount of leaf area a plant develops per unit total plant mass, was calculated as the ratio between leaf area and total plant biomass. The net assimilation rate (NAR, $\mathrm{g} \mathrm{cm}^{-2}$ day $^{-1}$ ), i.e., the net biomass gain expressed on leaf area basis, was calculated as follows:

$$
\mathrm{NAR}=\frac{\left(\mathrm{M}_{\mathrm{t}}-\mathrm{M}_{\mathrm{t}-1}\right) \times\left(\ln \mathrm{LA}_{\mathrm{t}}-\ln \mathrm{LA}_{\mathrm{t}-1}\right)}{\left(\mathrm{LA}_{\mathrm{t}}-\mathrm{LA}_{\mathrm{t}-1}\right) \times(\mathrm{t}-\mathrm{t}-1)}
$$

where $L A_{t}$ and $L A_{t-1}$ represent the leaf area $t$ and $t-1$, respectively, while $M_{t}$ and $M_{t-1}$ are previously described; time is expressed as DAT.

Dried sub-samples of pepper fruits (or flowers), stems and leaves were analyzed to determine their $\mathrm{N}$ concentration following the Kjeldahl digestion method; the analyses were performed in duplicate at 0,21, 42 and 83 DAT. At 83 DAT, analysis was also performed on separated green, ripening and mature fruits.

\subsection{Physiological Parameters}

The soil-plant analysis development (SPAD) and leaf temperature (TIR) assessments were performed on both Exp_1 and Exp_2 during all the crop cycle at 15, 31, 41, 52, 64, 91, and 104 DAT.

The SPAD 502 plus portable chlorophyll meter (Konica Minolta, Inc., Tokyo, Japan) was used to estimate chlorophyll content in five fully expanded and same sun-oriented leaves of three plants per experimental unit. 
Leaf temperature (TIR) was recorded with a portable infrared thermometer (Everest Interscience Inc., Tucson, AZ, USA), at $20 \mathrm{~cm}$ from the leaf surface (uppermost leaf of three plants per experimental unit).

Canopy reflectance was measured with a HandHeld 2 Pro Portable FieldSpec Spectroradiometer (ADS Inc., Boulder, CO, USA) on three plants per experimental unit, at 15, 41, and 91 DAT. The instrument measures spectra over a spectral range of 325-1075 nm. To minimize the effects of the sun's position, the reflectance measurements were taken within $1 \mathrm{~h}$, near solar noon. Some important literature vegetation indices was then calculated: normalized difference vegetation index (NDVI; [17]); green normalized difference vegetation index (GNDVI; [18]); modified chlorophyll absorption ratio index (MCARI; [19]); optimized soil-adjusted vegetation index (OSAVI; [20]); and water index (WI; [21]).

\subsection{Analytical Determination}

Leaf pigment concentrations were determined during the vegetative/early reproductive phase of the pepper growing cycle at 21 and 42 DAT. Starting from sampled materials (as described in Section 2.4), we selected three fully expanded leaves per plant, characterized by the same position on the plant (i.e., primary, or secondary branches) as well as the same growth stage. From these sub-samples, the foliar pigments, named chlorophyll (Chla), Chlb, and carotenoids (Car) were determined following the method described by Lichtenthaler and Buschmann [22]. The results were expressed in $\mu \mathrm{g} \mathrm{g}^{-1}$ of fresh weight (FW).

Cuticular waxes were determined by gravimetric analysis, as previously described [23]. Two uppermost fully expanded leaves per sampled plant was collected at 21 and 42 DAT. The amount of wax was expressed against leaf area (both leaves' surfaces), as determined by acquiring scanned leaves' images with an image analysis software (ImageJ, National Institutes of Health, Bethesda, MD, USA).

\subsection{Statistical Analysis}

A three-way analysis of variance (ANOVA) was applied to test (F-test) the effects of the experiment (Exp) and treatments ( $\mathrm{N}$ fertilization rates: $\mathrm{N} \_$rates; Sh levels: $\mathrm{Sh} \_$lev). Since no significant effects of 'Exp' or 'Exp $\times$ N_rates' or 'Exp $\times$ Sh_lev' or 'Exp $\times$ N_rates $\times$ Sh_lev' interactions were detected, we have reported in Tables and Figures only the main effects of treatments or their interaction. ANOVA assumptions were tested through graphical methods. The statistical analyses were performed using R software [24].

\section{Results}

\subsection{Growth Conditions}

The application of two photoselective nets sharply affected both the amount and quality of the radiation transmitted to the canopy with respect to Control. Figure 1A shows the evolution of daily values of DQI for the three light treatments: BN gave the lowest values while Control the highest. The highest PAR reduction was observed for BN $(40.4 \%$ of shading), followed by RN (23.8\%) with the former showing also the lowest relative amounts of scattered PAR ( $12.1 \%$ vs. $15.4 \%$ BN and RN, respectively; Table S2). BN reduced uniformly the radiance values, with no remarkable differences between wavelengths; conversely, $\mathrm{RN}$ showed a greater absorption around 350-550 nm (violet-green region) with respect to the other spectral bands (Figure 2).

Little differences were also recorded in terms of day-night thermal excursion, with RN showing the highest values $\left(10.7^{\circ} \mathrm{C}\right.$; Table S2), as well as of $\mathrm{RH}(58.4 \%, 57.8 \%$, and $59.6 \%$, for Control, RN, and BN, respectively; Table S2). However, these differences can be considered negligible. 
21 DAT

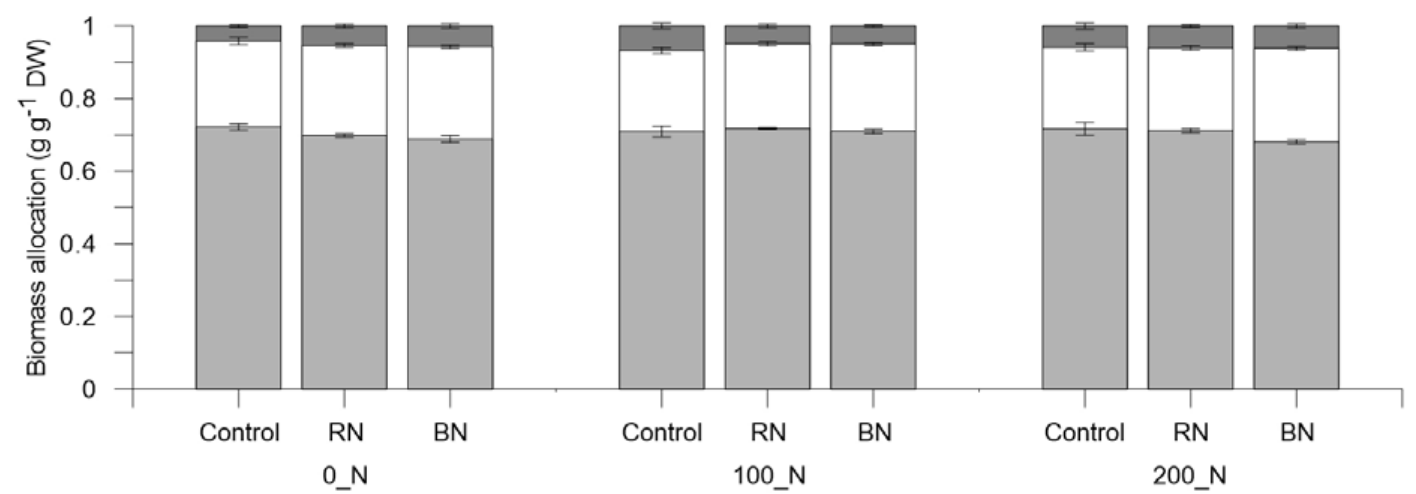

42 DAT

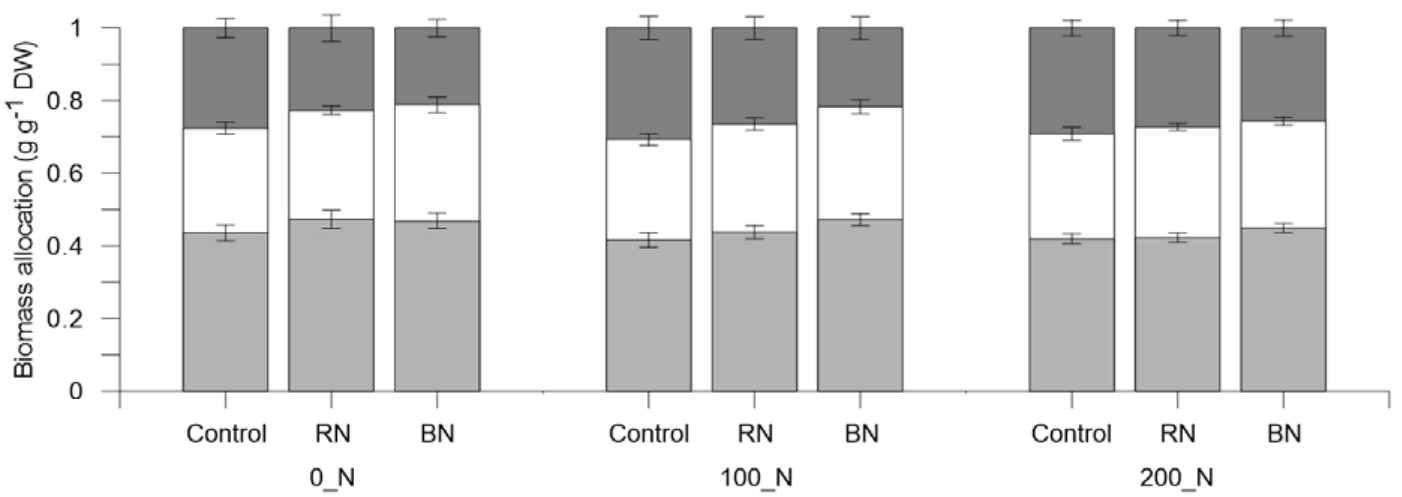

83 DAT

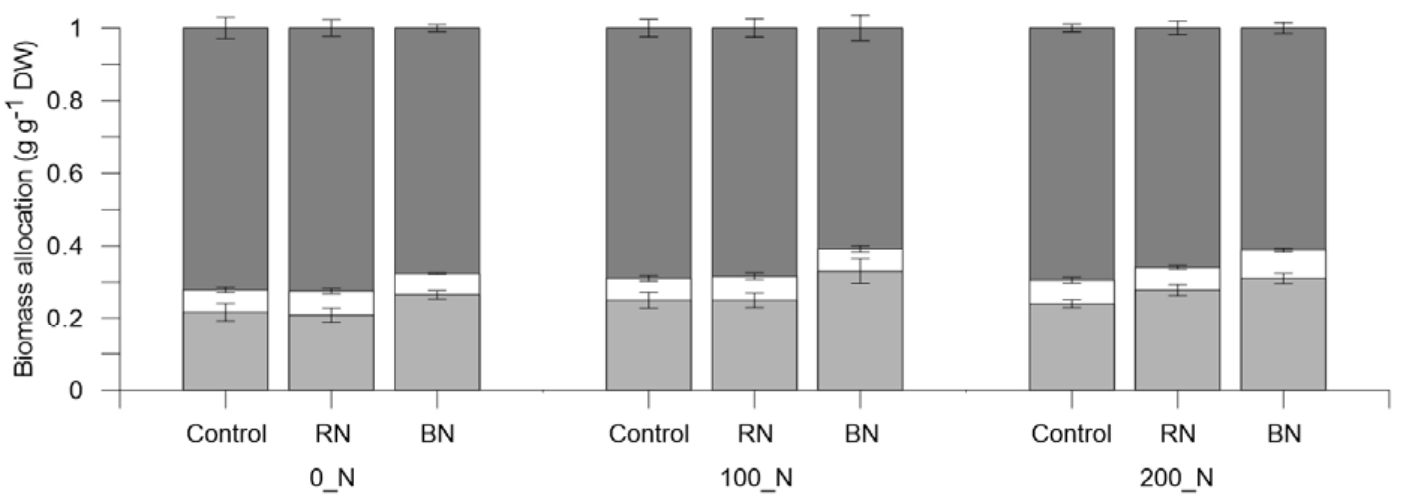

\begin{tabular}{llllllllll}
\hline & \multicolumn{3}{c}{ LMR } & \multicolumn{3}{c}{ SMR } & \multicolumn{3}{c}{ ReMR } \\
\cline { 2 - 10 } Effects & 21DAT & $42 D A T$ & 83DAT & 21DAT & 42DAT & 83DAT & 21DAT & 42DAT & 83DAT \\
\cline { 2 - 9 } N_rates & $0.35^{n s .}$ & $0.07^{n s}$ & $0.08^{n s}$ & $0.01^{*}$ & $0.80^{n s}$ & $0.38^{n s}$ & $0.20^{n s}$ & $0.26^{n s}$ & $0.10^{n s}$ \\
Sh_lev & $0.01^{*}$ & $<0.01^{*}$ & $<0.01^{*}$ & $<0.01^{*}$ & $0.23^{n s}$ & $0.78^{n s}$ & $0.89^{n s}$ & $0.05^{*}$ & $<0.01^{*}$ \\
N_rates x Sh_lev & $0.18^{n s}$ & $0.52^{n s}$ & $0.50^{n s}$ & $0.43^{n s}$ & $0.84^{n s}$ & $0.51^{n s}$ & $0.05^{n s}$ & $0.64^{n s}$ & $0.79^{n s}$
\end{tabular}

Figure 2. Biomass allocation among the structural aerial fractions of pepper plants subjected to different $\mathrm{N}$ fertilization rates (0_N: 0 kg N ha ${ }^{-1}$; 100_N: $100 \mathrm{~kg} \mathrm{~N} \mathrm{ha}^{-1}$; 200_N: $200 \mathrm{~kg} \mathrm{~N} \mathrm{ha}^{-1}$ ) and shading (Sh) levels (accomplished using: no cover, Control; red photoselective net, RN; black photoselective net, BN) at 21, 42 and 83 days after transplanting (DAT) in 2017. Light-gray chart: leaf mass ratio (LMR); white chart: stem mass ratio (SMR); deep-gray chart: reproductive organs (i.e., flowers and/or fruits) mass ratio (ReMR). Data are means \pm standard errors, over Exp_1 and Exp_2 $(n=6)$. In box, $p$-values from the analysis of variance (ANOVA) at $5 \%$ level of probability: N fertilization rates (N_rates); Sh levels (Sh_lev). ${ }^{*} p<0.05 ;{ }^{* *} p<0.01 ;$ n.s. $=$ not significant. 


\subsection{Growth Analysis and Morphological Parameters}

Vegetative and reproductive pepper' organs DWs and total DWs responses to $\mathrm{N}$ fertilization rates and Sh conditions are reported in Table 1. At 21 DAT, N availability was the most determining factor influencing plant growth; not significant differences between 100_N and 200_N were recorded. Similar behaviours were observed at both 42 and 83 DAT. The effect of Sh conditions was pretty unclear and was mainly significant at $42 \mathrm{DAT}$, with RN showing the higher DWs values; conversely, BN showed the significantly highest leaves DW at 83 DAT (Table 1).

In Figure 2 is reported the biomass allocation among vegetative and reproductive organs during the pepper crop cycle.

As expected, during the crop cycle the biomass allocated to vegetative organs (i.e., leaves and stems) basically decreased to the advantage of newly produced biomass allocated to fruits. However, the PAR transmitted to the canopy played a significant role in the biomass allocation process, especially in terms of LMR and ReMR (see the box in Figure 2). In particular, at $83 \mathrm{DAT}$, plants under BN showed significantly higher and lower values of LMR of ReMR respectively than RN and Control (LMR: 0.302 vs. 0.245 and $0.236 \mathrm{~g} \mathrm{~g}^{-1} \mathrm{DW}$ for BN, RN and Control, respectively; ReMR: 0.632 vs. 0.689 and $0.702 \mathrm{~g} \mathrm{~g}^{-1} \mathrm{DW}$ for BN, $\mathrm{RN}$ and Control, respectively) which recorded similar values (Figure 2).

Besides, $\mathrm{N}$ and light availability sharply affected the number of leaves per plant as well as the total and single leaf area (Table 2; see from 42 DAT). In particular, the NumLf seemed to decrease at higher Sh intensity, while the highest LA and single LA values were generally recorded under $\mathrm{BN}$ at the highest fertilization rates, although significance varied among treatments and DAT (see Table 2). Interesting, $\mathrm{RN}$, under $200 \mathrm{Kg} \mathrm{N} \mathrm{ha}^{-1}$, induced LA and single LA values comparable with those obtained under BN. Despite such a trend, SLA significantly differed only in the middle phase of the pepper cycle, with BN showing the highest values, regardless of $\mathrm{N}$ doses (Table 2).

Under low-PAR availability, stem length increased up to 42 DAT (Table 3). On the other hand, Sh $\times \mathrm{N}$ fertilization interaction seemed to significantly influence stem diameter at 42 and 83 DAT. In this case, the highest values were observed under shading for plants fertilized with 200 (or 100) $\mathrm{kg} \mathrm{N} \mathrm{ha}^{-1}$ (Table 3).

RGR was not affected by treatments, NAR significantly reduced under limited PAR conditions while LAR increased (Table 4).

\subsection{N Accumulation and Dynamics}

The dynamics of leaf+stem $\mathrm{N}$ content per shoot (NLw), total $\mathrm{N}$ content per shoot $(\mathrm{NTw})$, and leaf+stem $\mathrm{N}$ content per unit leaf area (NLa) during the pepper growing cycle are reported in Figure 3.

As expected, both NLw and NTw increased with fertilization rates; however, this increase was more pronounced under Control and RN treatments, especially in terms of NTw. Starting from the beginning of fruit formation (42 DAT), significantly increased the amount of $\mathrm{N}$ translocated to the growing fruits. Under the lowest $\mathrm{N}$ availability $\left(0 \_\mathrm{N}\right)$ shading stimulated $\mathrm{N}$ accumulation in harvested vegetative and reproductive organs (NLw: $1.19 \mathrm{~g} \mathrm{plant}^{-1}$ for BN vs. $0.80 \mathrm{~g} \mathrm{plant}^{-1}$, averaged over Control and RN; NTw: 3.37 g plant $^{-1}$ for BN vs. 2.71 g plant $^{-1}$, averaged over Control and RN). Conversely, in fertilized plants the amount of $\mathrm{N}$ translocated to fruits seemed to decrease in response to Sh conditions (83 DAT). Regardless of PAR availability, the amount of $\mathrm{N}$ directed to fruits was higher in N_200 rather than N_100 (Figure 3).

$\mathrm{N}$ fertilization induced also higher NLa values (Figure 3). An unclear pattern emerged in response to Sh or ShxN dose interaction. At $83 \mathrm{DAT}, \mathrm{BN}$ showed the highest NLa values at $0 \_\mathrm{N}$ and the lowest at 200_N (Figure 3; 0_N: 0.79, 0.73, and $0.82 \mathrm{~g} \mathrm{~cm}^{-2}$ for Control, $\mathrm{RN}$, and BN, respectively; 100_N: 0.92, 0.90, and $0.90 \mathrm{~g} \mathrm{~cm}^{-2}$ for Control, RN, and BN, respectively; 200_N: 0.93, 0.78, and $0.67 \mathrm{~g} \mathrm{~cm}^{-2}$ for Control, $\mathrm{RN}$, and $\mathrm{BN}$, respectively). 


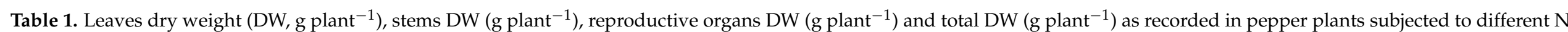

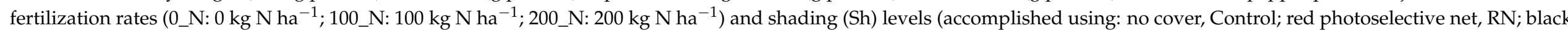

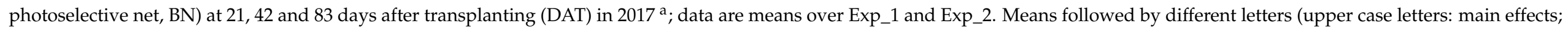
lower case letters: effects of interaction) significantly differ (Fisher's LSD, $p<0.05$ ).

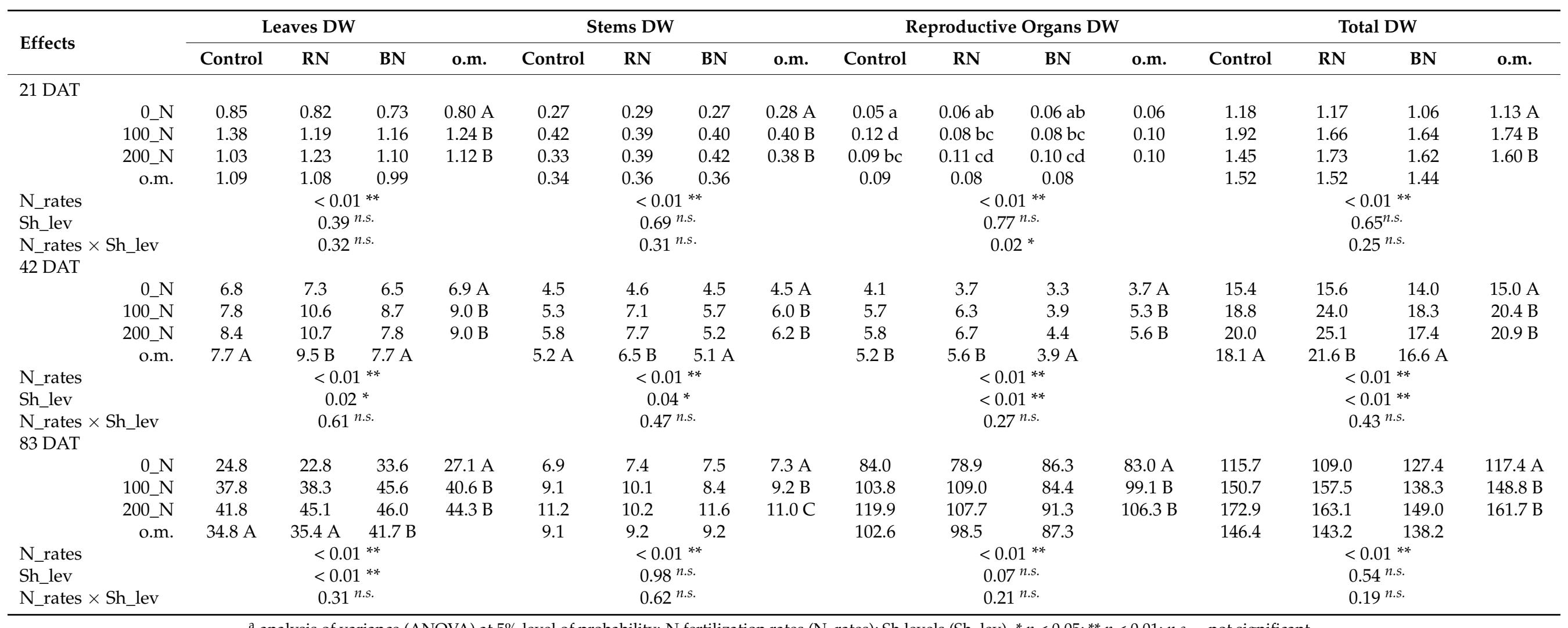

${ }^{\mathrm{a}}$ analysis of variance (ANOVA) at $5 \%$ level of probability: $\mathrm{N}$ fertilization rates (N_rates); Sh levels (Sh_lev). ${ }^{*} p<0.05 ;{ }^{* *} p<0.01 ; n . s .=$ not significant. 


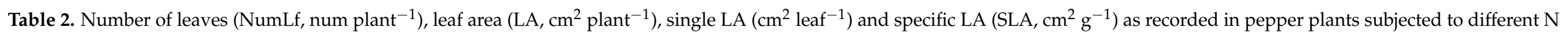

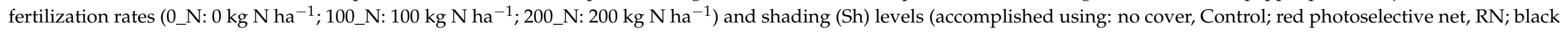

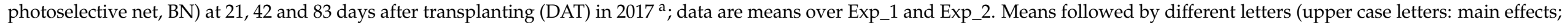
lower case letters: effects of interaction) significantly differ (Fisher's LSD, $p<0.05$ ).

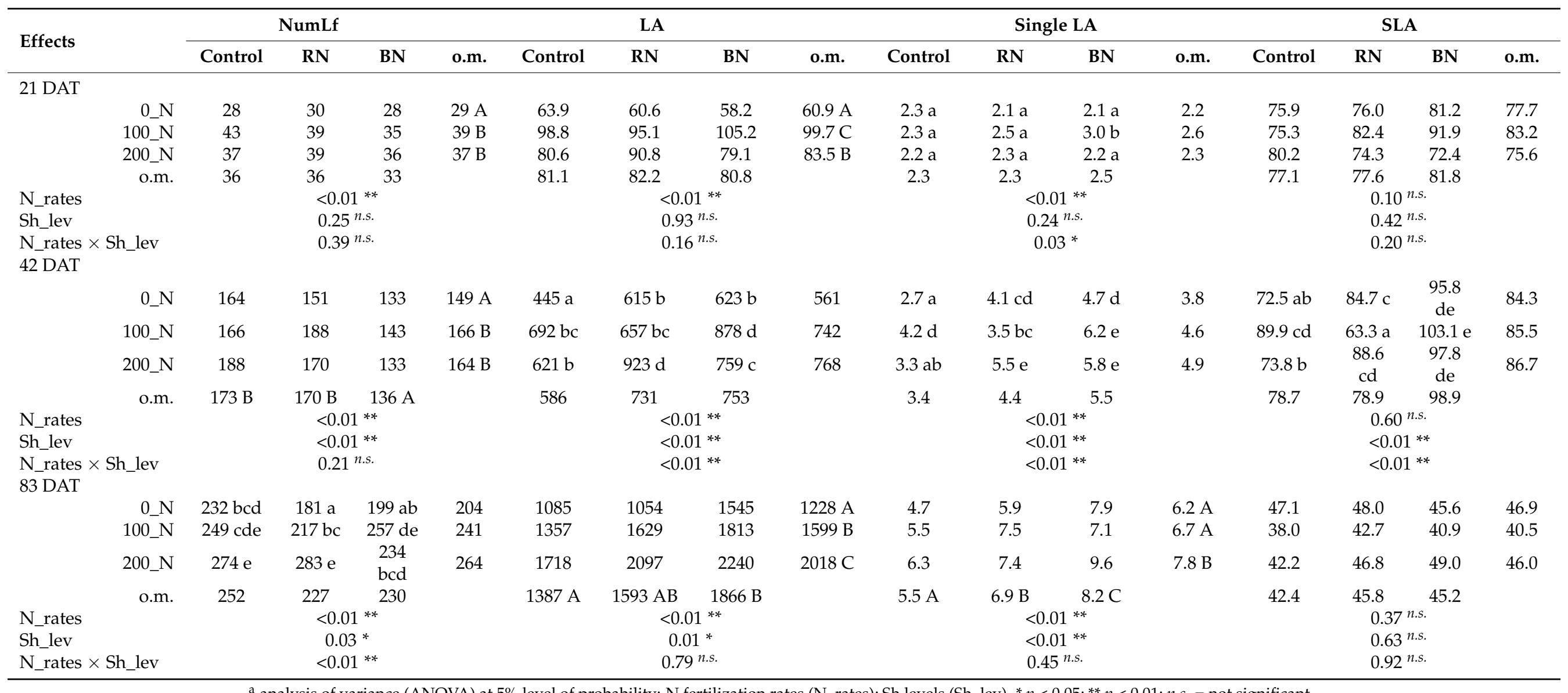

${ }^{\mathrm{a}}$ analysis of variance (ANOVA) at $5 \%$ level of probability: $\mathrm{N}$ fertilization rates (N_rates); Sh levels (Sh_lev). ${ }^{*} p<0.05 ;{ }^{* *} p<0.01 ; n . s .=$ not significant. 


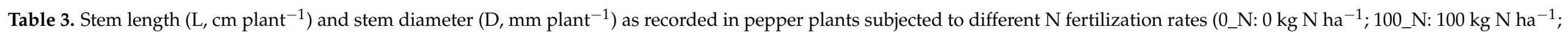

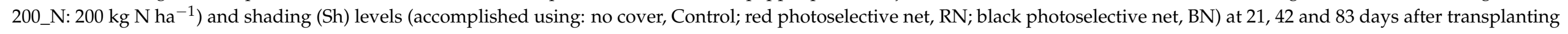

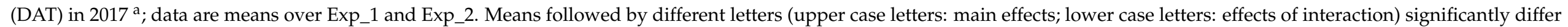
(Fisher's LSD, $p<0.05)$.

\begin{tabular}{|c|c|c|c|c|c|c|c|c|}
\hline \multirow{2}{*}{ Effects } & \multicolumn{4}{|c|}{$\mathbf{L}$} & \multicolumn{4}{|c|}{ D } \\
\hline & Control & RN & BN & o.m. & Control & RN & BN & o.m. \\
\hline \multicolumn{9}{|l|}{21 DAT } \\
\hline 0_N & 14.8 & 15.2 & 15.0 & 15.0 & 3.41 & 3.65 & 3.71 & $3.59 \mathrm{~A}$ \\
\hline 100_N & 14.3 & 15.7 & 16.6 & 15.5 & 4.54 & 4.39 & 4.33 & $4.42 \mathrm{~B}$ \\
\hline 200_N & 15.0 & 15.6 & 15.7 & 15.4 & 4.17 & 4.73 & 4.56 & $4.48 \mathrm{~B}$ \\
\hline o.m. & $14.7 \mathrm{~A}$ & $15.5 \mathrm{~B}$ & $15.8 \mathrm{~B}$ & & 4.04 & 4.26 & 4.20 & \\
\hline N_rates & & & & & & & & \\
\hline Sh_lev & & & & & & & & \\
\hline N_rates $\times$ Sh_lev & & & & & & & & \\
\hline \multicolumn{9}{|l|}{$42 \mathrm{DAT}$} \\
\hline 0_N & 31.28 & 34.73 & 38.23 & $34.74 \mathrm{~A}$ & $7.49 \mathrm{a}$ & $7.95 \mathrm{abcd}$ & 8.36 cde & 7.93 \\
\hline 100_N & 34.18 & 40.50 & 41.68 & $38.78 \mathrm{~B}$ & $7.88 \mathrm{abc}$ & $8.37 \mathrm{de}$ & 8.73 ef & 8.32 \\
\hline 200_N & 33.88 & 38.66 & 40.38 & $37.64 \mathrm{~B}$ & $7.71 \mathrm{ab}$ & $9.05 \mathrm{f}$ & $8.12 \mathrm{bcd}$ & 8.29 \\
\hline o.m. & $33.11 \mathrm{~A}$ & $37.96 \mathrm{~B}$ & $40.09 \mathrm{~B}$ & & 7.69 & 8.46 & 8.40 & \\
\hline N_rates & & & & & & & & \\
\hline Sh_lev & & & & & & & & \\
\hline N_rates $\times$ Sh_lev & & & & & & & & \\
\hline \multicolumn{9}{|l|}{83 DAT } \\
\hline 100_N & 36.3 & 36.2 & 38.8 & 37.1 & $11.4 \mathrm{de}$ & 11.2 cde & $11.5 \mathrm{e}$ & 11.3 \\
\hline 200_N & 37.5 & 38.7 & 38.0 & 38.1 & $10.9 \mathrm{~cd}$ & $11.4 \mathrm{de}$ & $12.0 \mathrm{f}$ & 11.4 \\
\hline o.m. & 36.3 & 37.3 & 38.1 & & 10.9 & $10.8 \mathrm{~B}$ & 11.4 & \\
\hline N_rates & & & & & & & & \\
\hline Sh_lev & & & & & & & & \\
\hline N_rates $\times$ Sh_lev & & & & & & & & \\
\hline
\end{tabular}

${ }^{a}$ analysis of variance (ANOVA) at $5 \%$ level of probability: $\mathrm{N}$ fertilization rates (N_rates); Sh levels (Sh_lev). ${ }^{*} p<0.05 ;{ }^{* *} p<0.01 ; n . s .=$ not significant. 


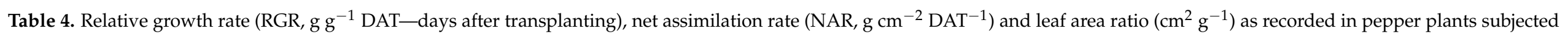

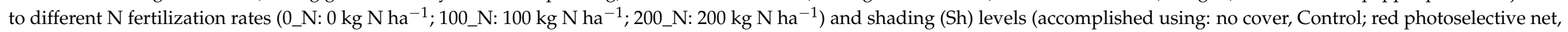

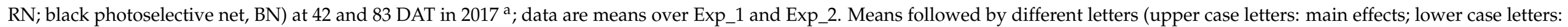
effects of interaction) significantly differ (Fisher's LSD, $p<0.05$ ).

\begin{tabular}{|c|c|c|c|c|c|c|c|c|c|c|c|c|c|}
\hline \multirow{2}{*}{\multicolumn{2}{|c|}{ Effects }} & \multicolumn{3}{|c|}{ RGR } & \multicolumn{5}{|c|}{ NAR } & \multicolumn{4}{|c|}{ LAR } \\
\hline & & Control & RN & BN & o.m. & Control & RN & BN & o.m. & Control & RN & BN & o.m. \\
\hline \multicolumn{14}{|l|}{42 DAT } \\
\hline & 0_N & 0.120 & 0.123 & 0.124 & 0.123 & 0.0033 def & $0.0029 \mathrm{bcd}$ & $0.0027 \mathrm{bc}$ & 0.0029 & 42.7 & 46.6 & 49.8 & $46.4 \mathrm{AB}$ \\
\hline & 100_N & 0.110 & 0.127 & 0.115 & 0.117 & $0.0026 \mathrm{abc}$ & $0.0037 \mathrm{f}$ & $0.0022 \mathrm{a}$ & 0.0028 & 45.0 & 43.5 & 56.9 & $48.5 \mathrm{~B}$ \\
\hline & 200_N & 0.127 & 0.127 & 0.113 & 0.122 & 0.0034 ef & 0.0031 cde & $0.0025 \mathrm{ab}$ & 0.0030 & 44.6 & 45.1 & 46.6 & $45.4 \mathrm{~A}$ \\
\hline & o.m. & 0.119 & 0.126 & 0.117 & & 0.0031 & 0.0032 & 0.0024 & & $44.1 \mathrm{~A}$ & $45.1 \mathrm{~A}$ & $51.1 \mathrm{~B}$ & \\
\hline N_rates & & \multicolumn{4}{|c|}{$0.22^{n . s}$} & \multicolumn{4}{|c|}{$0.24^{n . s .}$} & \multicolumn{4}{|c|}{$0.04^{*}$} \\
\hline Sh_lev & & \multicolumn{4}{|c|}{$0.05^{\text {n.s. }}$} & \multicolumn{4}{|c|}{$<0.01^{* *}$} & \multicolumn{4}{|c|}{$<0.01^{* *}$} \\
\hline \multicolumn{2}{|c|}{ N_rates $\times$ Sh_lev } & \multicolumn{4}{|c|}{$0.07^{n . s .}$} & \multicolumn{4}{|c|}{$<0.01^{* *}$} & \multicolumn{4}{|c|}{$0.06^{n . s .}$} \\
\hline & 0_N & 0.050 & 0.048 & 0.054 & 0.051 & 0.0035 & 0.0028 & 0.0028 & 0.0030 & $20.1 \mathrm{a}$ & $24.9 \mathrm{~cd}$ & $27.7 \mathrm{de}$ & 24.2 \\
\hline & 100_N & 0.051 & 0.046 & 0.050 & 0.049 & 0.0033 & 0.0031 & 0.0023 & 0.0029 & $23.1 \mathrm{bc}$ & $19.1 \mathrm{a}$ & $30.9 \mathrm{f}$ & 24.4 \\
\hline & 200_N & 0.053 & 0.046 & 0.053 & 0.050 & 0.0036 & 0.0024 & 0.0024 & 0.0028 & $20.6 \mathrm{ab}$ & $25.1 \mathrm{~cd}$ & 29.4 ef & 25.0 \\
\hline & o.m. & 0.051 & 0.046 & 0.052 & & $0.0035 \mathrm{~B}$ & $0.0028 \mathrm{~A}$ & $0.0025 \mathrm{~A}$ & & 21.3 & 23.0 & 29.3 & \\
\hline N_rates & & \multicolumn{4}{|c|}{$0.59^{n . s .}$} & \multicolumn{4}{|c|}{$0.44^{n . s .}$} & \multicolumn{4}{|c|}{$0.64^{n . s .}$} \\
\hline Sh_lev & & \multicolumn{4}{|c|}{$0.06^{\text {n.s. }}$} & \multicolumn{4}{|c|}{$<0.01 * *$} & \multicolumn{4}{|c|}{$<0.01^{* *}$} \\
\hline N_rates & & \multicolumn{4}{|c|}{$0.93^{\text {n.s. }}$} & \multicolumn{4}{|c|}{$0.33^{\text {n.s. }}$} & \multicolumn{4}{|c|}{$<0.01^{* *}$} \\
\hline
\end{tabular}

${ }^{\mathrm{a}}$ analysis of variance (ANOVA) at $5 \%$ level of probability: $\mathrm{N}$ fertilization rates (Fact_1); Sh levels (Sh_lev). ${ }^{*} p<0.05 ;{ }^{* *} p<0.01 ; n . s .=$ not significant. 

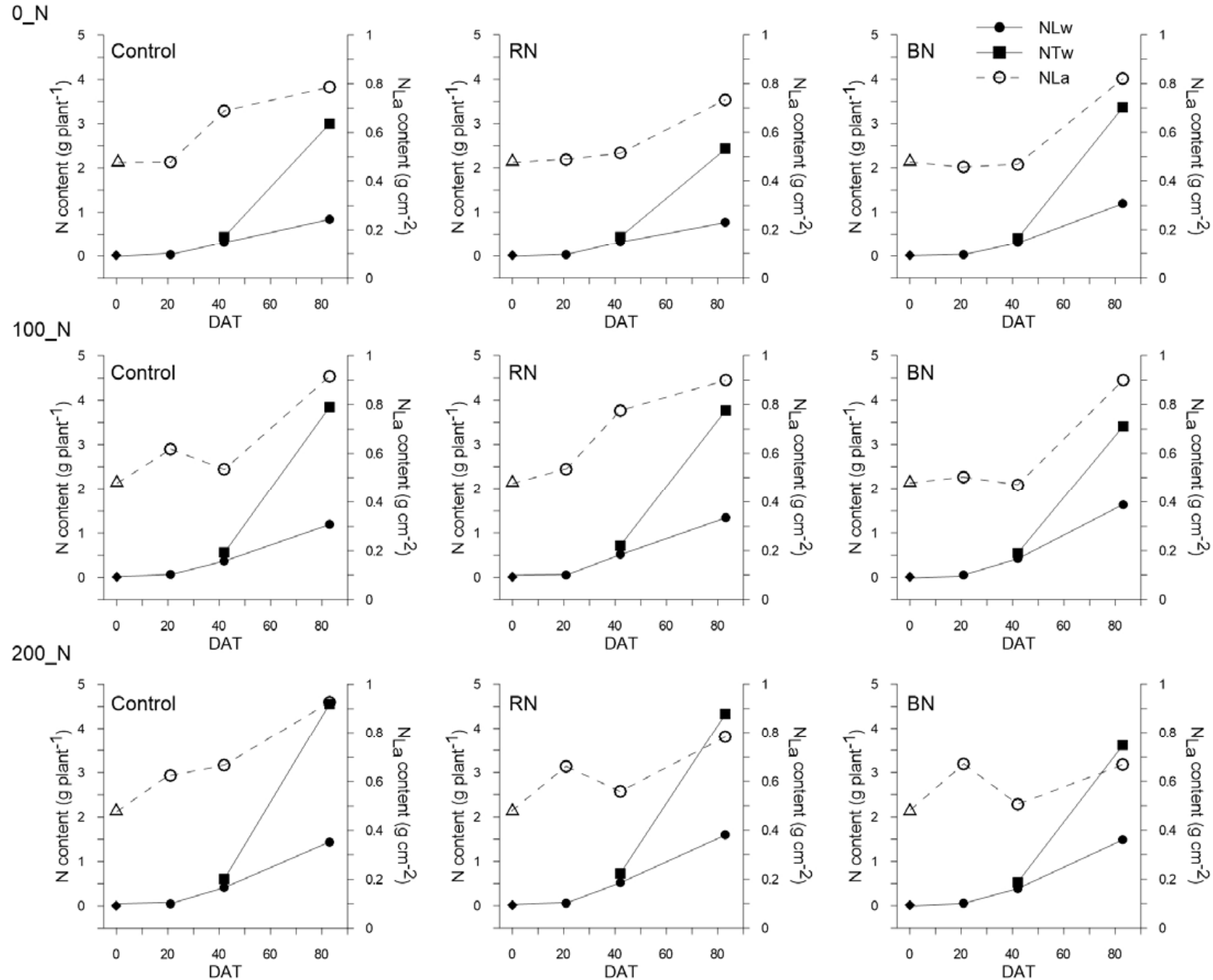

Figure 3. Time course of leaf+stem $\mathrm{N}$ content per shoot $\left(\mathrm{NLw}, \mathrm{g}\right.$ plant $\left.{ }^{-1}\right)$, total $\mathrm{N}$ content per shoot $\left(\mathrm{NTw}, \mathrm{g}\right.$ plant $\left.{ }^{-1}\right)$-left $\mathrm{y}^{-}$ axis—and leaf+stem $\mathrm{N}$ content per unit leaf area $\left(\mathrm{NLa}, \mathrm{g} \mathrm{cm}^{-2}\right)$-right y-axis—from transplanting (0 days after transplanting, DAT) till 83 DAT. represents the NLw value recorded at 0 DAT, before the treatments application; $\Delta$ represents the NLa value recorded at 0 DAT, before the treatments application. Data are averaged over Exp_1 and Exp_2, for $n=6$. Aggregated mean values of the standard errors are: NLw, $\pm 0.032 \mathrm{~g} \mathrm{plant}^{-1}$ for $0 \_\mathrm{N}, \pm 0.051 \mathrm{~g}$ plant $^{-1}$ for $100 \_\mathrm{N}, \pm 0.044 \mathrm{~g} \mathrm{plant}^{-1}$ for 200_N; NTw, \pm 0.247 g plant $^{-1}$ for 0_N, $\pm 0.240 \mathrm{~g} \mathrm{plant}^{-1}$ for 100_N, $\pm 0.288 \mathrm{~g} \mathrm{plant}^{-1}$ for 200_N; NLa, $\pm 0.041 \mathrm{~g} \mathrm{~cm}^{-2}$ for 0_N, $\pm 0.048 \mathrm{~g} \mathrm{~cm}^{-2}$ for 100_N, $\pm 0.051 \mathrm{~g} \mathrm{~cm}^{-2}$ for 200_N.

$\mathrm{N}$ concentration data partially confirmed those observed in terms of $\mathrm{N}$ content (Figure 4). $\mathrm{N}$ fertilization sharply contributed to differences in terms of $\mathrm{N}$ concentration in fruits, whit higher values in 200_N and without significant differences among Sh conditions (Figure 4).

\subsection{Physiological Adjustments to Growth Conditions}

$\mathrm{N}$ fertilization as well as Sh conditions significantly affected SPAD values (see the box in Figure 5); such differences tended to decrease later in the crop cycle. In general, $\mathrm{N}$ fertilization enhanced the estimated chlorophyll content in pepper leaves $(52.9,56.1$, and 56.3 for 0_N, 100_N, and 200_N, respectively, averaged over Sh and DAT), while the higher SPAD values were assured by fully-light conditions (56.6, 54.0, and 54.7 for Control, RN, and $\mathrm{BN}$, respectively, averaged over $\mathrm{N}$ rates and $\mathrm{DAT})$. 

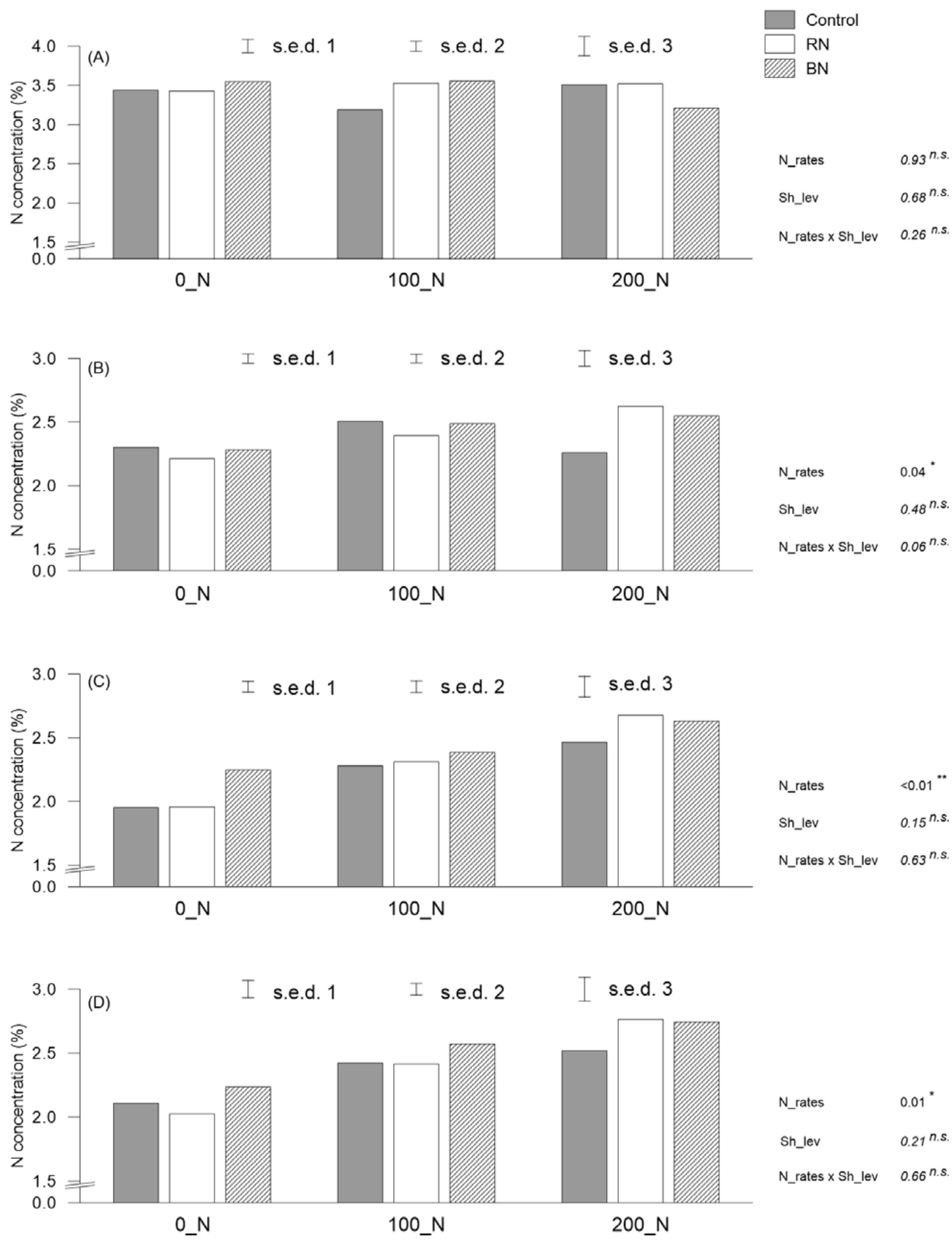

Figure 4. $\mathrm{N}$ concentration in the structural aerial fractions (A), leaves + stems; $(\mathbf{B})$, green fruits; (C) ripening fruits; (D), mature fruits) of pepper plants subjected to different $\mathrm{N}$ fertilization rates $0 \_\mathrm{N}: 0 \mathrm{~kg} \mathrm{~N} \mathrm{ha}{ }^{-1} ; 100 \_\mathrm{N}: 100 \mathrm{~kg} \mathrm{~N} \mathrm{ha}{ }^{-1}$; 200_N: $200 \mathrm{~kg} \mathrm{~N} \mathrm{ha}^{-1}$ ) and shading (Sh) levels (accomplished using: no cover, Control; red photoselective net, RN; black photoselective net, BN) at 83 days after transplanting (DAT) in 2017. Data are means, over Exp_1 and Exp_2, for $n=6$. In boxes, significance from the analysis of variance (ANOVA) at $5 \%$ level of probability: $\mathrm{N}$ fertilization rates (N_rates); Sh levels (Sh_lev). Vertical bars represent the standard errors of the difference between means (s.e.d.) for N_rates (s.e.d. 1), Sh_lev (s.e.d. 2) and N_rates $\times$ Sh_lev (s.e.d. 3$) .{ }^{*} p<0.05 ;{ }^{* *} p<0.01 ; n . s .=$ not significant. 

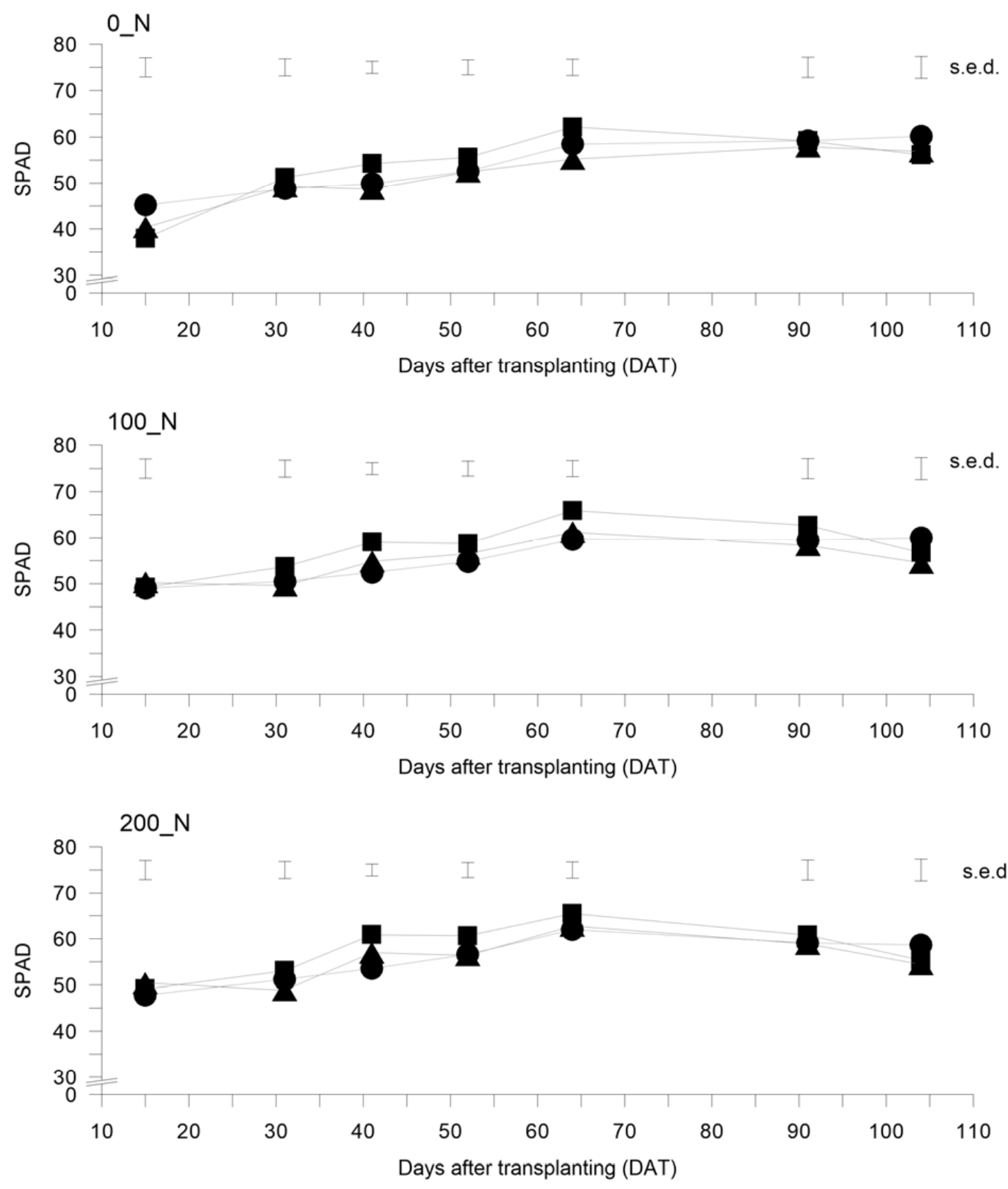

\begin{tabular}{llllllll}
\hline \multirow{2}{*}{ Effects } & \multicolumn{7}{c}{ DAT } \\
\cline { 2 - 7 } & 15 & 31 & 41 & 52 & 64 & 91 & 104 \\
\hline N_rates & $<0.01^{* *}$ & $0.56^{\text {n.s. }}$ & $<0.01^{* *}<0.01^{* *} 0.03^{*}$ & $0.70^{\text {n.s. }}$ & $0.71^{\text {n.s. }}$ \\
Sh_lev & $0.25^{\text {n.s. }}$ & $<0.01^{* *}<0.01^{* *}$ & $<0.01^{* *}<0.01^{* *}$ & $0.07^{\text {n.s. }}$ & $<0.01^{\text {** }}$ \\
N_rates $x$ Sh_lev & $0.04^{*}$ & $0.63^{\text {n.s. }}$ & $0.10^{\text {n.s. }}$ & $0.86^{\text {n.s. }}$ & $0.04^{*}$ & $0.68^{\text {n.s. }}$ & $0.80^{\text {n.s. }}$ \\
\hline
\end{tabular}

Figure 5. Dynamic of SPAD as recorded during the growth cycle of pepper plants subjected to different $\mathrm{N}$ fertilization rates 0_N: 0 kg N ha ${ }^{-1} ; 100 \_\mathrm{N}: 100 \mathrm{~kg} \mathrm{~N} \mathrm{ha}^{-1} ; 200 \_\mathrm{N}: 200 \mathrm{~kg} \mathrm{~N} \mathrm{ha}^{-1}$ ) and shading (Sh) levels (accomplished using: no cover, Control; red photoselective net, RN; black photoselective net, $\mathrm{BN}$ ), in 2017. Control: black squares; RN: black triangles; $\mathrm{BN}$ : black circles. Data are means, over Exp_1 and Exp_2, for $n=6$. In boxes, significance from the analysis of variance (ANOVA) at $5 \%$ level of probability: $\mathrm{N}$ fertilization rates (N_rates); Sh levels (Sh_lev). At each sampling date, vertical bars represent the standard errors of the difference between means (s.e.d.) for N_rates $\times$ Sh_lev. ${ }^{*} p<0.05 ;{ }^{* *} p<0.01 ; n$.s. $=$ not significant. 
SPAD results were partially confirmed by the Chl concentration in pepper leaves, recorded only during the early stages of the crop growing cycle (Table 5). Indeed, at 21 DAT, $\mathrm{Chl}$ content increased as $\mathrm{N}$ availability and Sh levels increased. However, these differences disappeared as the cycle went on (Table 5).

Table 5. Chlorophyll a (Chla, $\left.\mu \mathrm{g} \mathrm{g}^{-1} \mathrm{FW}\right), \mathrm{Chlb}\left(\mu \mathrm{g} \mathrm{g}{ }^{-1} \mathrm{FW}\right)$, and carotenoid (Car, $\left.\mu \mathrm{g} \mathrm{g}^{-1} \mathrm{FW}\right)$ concentration as determined in leaves of pepper plants subjected to different $\mathrm{N}$ fertilization rates $\left(0 \_\mathrm{N}: 0 \mathrm{~kg} \mathrm{~N}\right.$ ha ${ }^{-1} ; 100 \_\mathrm{N}: 100 \mathrm{~kg} \mathrm{~N}$ ha ${ }^{-1} ; 200 \_\mathrm{N}$ : $200 \mathrm{~kg} \mathrm{~N} \mathrm{ha}^{-1}$ ) and shading (Sh) levels (accomplished using: no cover, Control; red photoselective net, RN; black photoselective net, BN) at 21 and 42 days after transplanting (DAT) in 2017 ; d data are means over Exp_1 and Exp_2. Means followed by different letters (upper case letters: main effects; lower case letters: effects of interaction) significantly differ (Fisher's LSD, $p<0.05$ ).

\begin{tabular}{|c|c|c|c|c|c|c|c|c|}
\hline \multirow{2}{*}{ Effects } & \multicolumn{4}{|c|}{21 DAT } & \multicolumn{4}{|c|}{42 DAT } \\
\hline & Control & RN & BN & o.m. & Control & RN & BN & o.m. \\
\hline \multicolumn{9}{|l|}{ Chla } \\
\hline 0_N & 1237.3 & 1256.9 & 1534.8 & $1343.0 \mathrm{~A}$ & 1533.6 & 1522.3 & 1688.4 & 1581.4 \\
\hline 100_N & 1367.4 & 1552.6 & 1556.8 & $1492.3 \mathrm{~B}$ & 1688.5 & 1702.8 & 1631.8 & 1674.4 \\
\hline 200_N & 1382.8 & 1440.3 & 1618.6 & $1480.6 \mathrm{AB}$ & 1874.0 & 1751.3 & 1801.5 & 1808.9 \\
\hline o.m. & $1329.2 \mathrm{~A}$ & $1416.6 \mathrm{AB}$ & $1570.1 \mathrm{~B}$ & & 1698.7 & 1658.8 & 1707.2 & \\
\hline N_rates & \multicolumn{4}{|c|}{$<0.01 * *$} & \multicolumn{4}{|c|}{$0.14^{\text {n.s. }}$} \\
\hline Sh_lev & \multicolumn{4}{|c|}{$<0.01^{* *}$} & \multicolumn{4}{|c|}{$0.91^{\text {n.s. }}$} \\
\hline N_rates $\times$ Sh_lev & \multirow{2}{*}{\multicolumn{4}{|c|}{$0.55^{n . s .}$}} & \multicolumn{4}{|c|}{$0.89^{\text {n.s. }}$} \\
\hline \multicolumn{7}{|l|}{ Chlb } & & \\
\hline 0_N & 523.6 & 527.8 & 658.4 & $569.9 \mathrm{~A}$ & 660.1 & 656.8 & 692.0 & 669.7 \\
\hline 100_N & 586.6 & 713.2 & 707.5 & $669.1 \mathrm{~B}$ & 705.8 & 703.4 & 693.6 & 700.9 \\
\hline 200_N & 593.1 & 577.5 & 682.8 & $617.8 \mathrm{AB}$ & 805.6 & 736.1 & 774.7 & 772.1 \\
\hline o.m. & $567.8 \mathrm{~A}$ & $606.2 \mathrm{AB}$ & $682.9 \mathrm{~B}$ & & 723.9 & 698.8 & 720.1 & \\
\hline N_rates & \multicolumn{4}{|c|}{$0.03 *$} & \multicolumn{4}{|c|}{$0.13^{\text {n.s. }}$} \\
\hline Sh_lev & \multicolumn{4}{|c|}{$0.02 *$} & \multicolumn{4}{|c|}{$0.87^{\text {n.s. }}$} \\
\hline N_rates $\times$ Sh_lev & \multirow{2}{*}{\multicolumn{4}{|c|}{$0.46^{\text {n.s. }}$}} & \multirow{2}{*}{\multicolumn{4}{|c|}{$0.97^{n . s .}$}} \\
\hline Car & & & & & & & & \\
\hline 0_N & 412.4 & 418.8 & 438.6 & $423.2 \mathrm{~A}$ & 464.6 & 426.4 & 452.6 & 447.9 \\
\hline $100 \_N$ & 430.0 & 461.5 & 486.2 & $459.2 \mathrm{AB}$ & 526.1 & 474.8 & 464.5 & 488.5 \\
\hline 200_N & 475.6 & 459.7 & 481.1 & $472.1 \mathrm{~B}$ & 567.2 & 500.2 & 505.7 & 524.4 \\
\hline o.m. & 439.3 & 446.7 & 468.6 & & 519.3 & 467.1 & 474.3 & \\
\hline N_rates & \multicolumn{4}{|c|}{$<0.01 * *$} & \multicolumn{4}{|c|}{$0.14^{\text {n.s. }}$} \\
\hline Sh_lev & \multicolumn{4}{|c|}{$0.19^{\text {n.s. }}$} & \multicolumn{4}{|c|}{$0.27^{\text {n.s. }}$} \\
\hline N_rates $\times$ Sh_lev & \multicolumn{4}{|c|}{$0.72^{\text {n.s. }}$} & \multicolumn{4}{|c|}{$0.97^{\text {n.s. }}$} \\
\hline
\end{tabular}

${ }^{\mathrm{a}}$ analysis of variance (ANOVA) at $5 \%$ level of probability: $\mathrm{N}$ fertilization rates (N_rates); Sh levels (Sh_lev). o.m.: overall means. ${ }^{*} p<0.05$;

** $p<0.01 ; n$.s. $=$ not significant.

Vegetation indices from canopy reflectance are reported in Table 6. The first four VIs i.e., NDVI, GNDVI, MCARI, and OSAVI, are somehow linked to crop physiology, green biomass and Chl content and their values describe an unclear pattern. Fact_2 seemed to mostly affect canopy reflectance, especially in the middle phases of the crop cycle, and in the case of MCARI (with no significant differences between RN and BN), OSAVI and NDVI (with BN showing significantly higher values than RN and Control); on the other hand, full-light assured the highest GNDVI values (Table 6).

WI, as an indicator of crop water status, was influenced by the photoselective nets, starting from 41 DAT; the lowest values were observed under shaded conditions (Table 6).

Regardless of $\mathrm{N}$ fertilization rates, $\mathrm{Sh}$ induced progressive lower (as the level of shading progresses) TIR values during all the crop growing cycle $\left(29.0,27.8\right.$, and $26.5^{\circ} \mathrm{C}$ for Control, RN, and BN, respectively, averaged over N rates and DAT; Figure 6). 


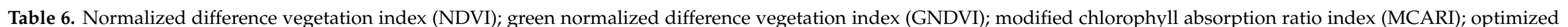

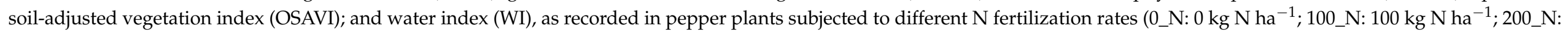

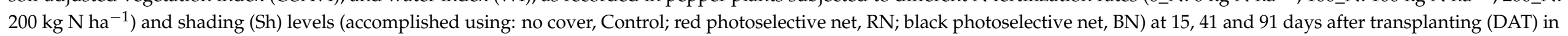

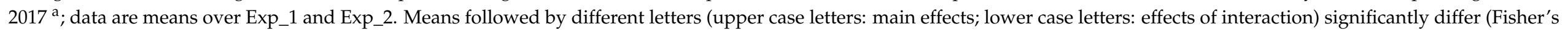
LSD, $p<0.05$ ).

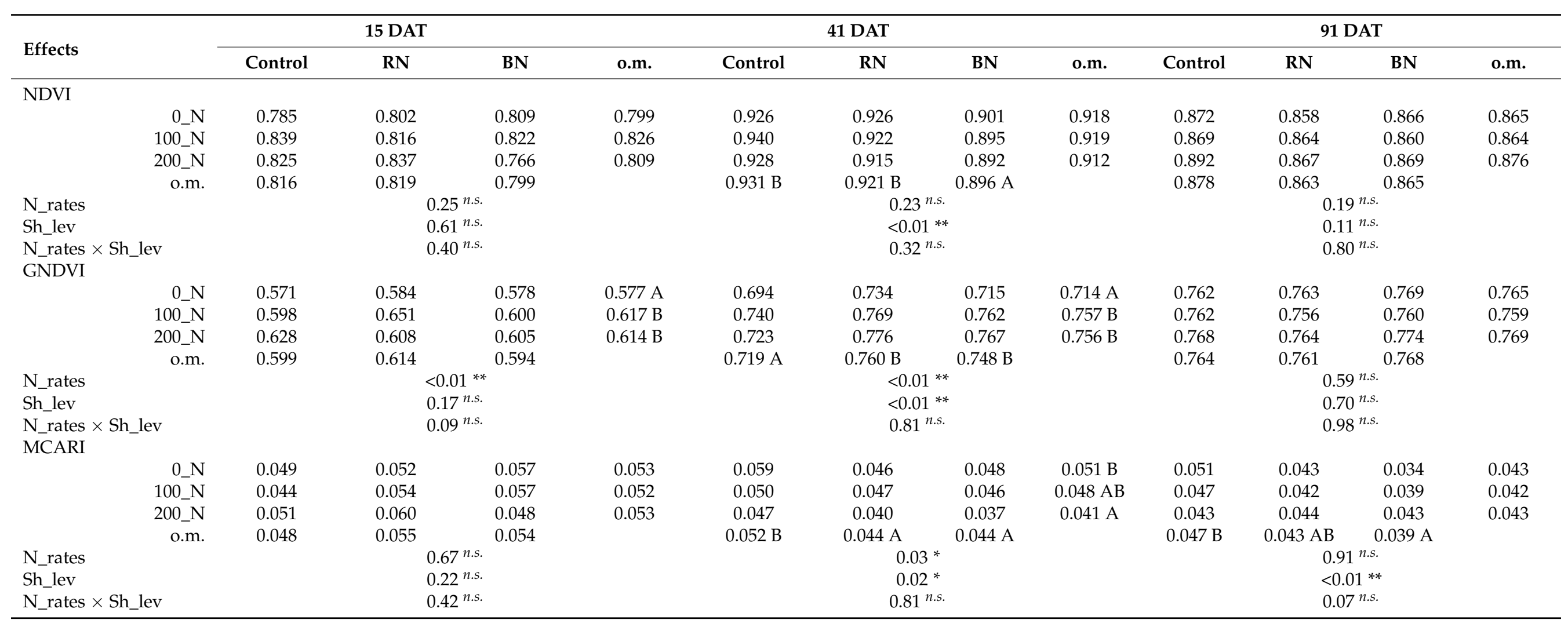


Table 6. Cont.

\begin{tabular}{|c|c|c|c|c|c|c|c|c|c|c|c|c|}
\hline \multirow{2}{*}{ Effects } & \multicolumn{3}{|c|}{15 DAT } & \multicolumn{5}{|c|}{41 DAT } & \multicolumn{4}{|c|}{91 DAT } \\
\hline & Control & RN & BN & o.m. & Control & $\mathbf{R N}$ & BN & o.m. & Control & RN & BN & o.m. \\
\hline \multicolumn{13}{|l|}{ OSAVI } \\
\hline 0_N & 0.633 & 0.654 & 0.644 & 0.644 & 0.880 & 0.886 & 0.844 & 0.870 & 0.837 & 0.820 & 0.827 & 0.828 \\
\hline 100_N & 0.698 & 0.649 & 0.611 & 0.653 & 0.888 & 0.883 & 0.852 & 0.874 & 0.851 & 0.831 & 0.837 & 0.840 \\
\hline 200_N & 0.712 & 0.667 & 0.674 & 0.684 & 0.894 & 0.886 & 0.863 & 0.881 & 0.834 & 0.846 & 0.857 & 0.845 \\
\hline o.m. & 0.681 & 0.656 & 0.643 & & $0.888 \mathrm{~B}$ & $0.885 \mathrm{~B}$ & $0.853 \mathrm{~A}$ & & 0.841 & 0.832 & 0.840 & \\
\hline N_rates & \multicolumn{4}{|c|}{$0.21^{\text {n.s. }}$} & \multicolumn{4}{|c|}{$0.16^{\text {n.s. }}$} & \multicolumn{4}{|c|}{$0.11^{\text {n.s. }}$} \\
\hline Sh_lev & \multicolumn{4}{|c|}{$0.27^{\text {n.s. }}$} & \multicolumn{4}{|c|}{$<0.01 * *$} & \multicolumn{4}{|c|}{$0.53^{\text {n.s. }}$} \\
\hline $\begin{array}{l}\text { N_rates } \times \text { Sh_lev } \\
\text { WI }\end{array}$ & \multicolumn{4}{|c|}{$0.50^{n . s .}$} & \multicolumn{4}{|c|}{$0.77^{n . s .}$} & \multicolumn{4}{|c|}{$0.37^{n . s .}$} \\
\hline $\begin{array}{l}\text { WI } \\
0 \_\mathrm{N}\end{array}$ & 1.047 & 1.059 & 1.057 & 1.054 & 1.101 & 1.099 & 1.062 & 1.088 & 1.140 & 1.078 & 1.036 & 1.085 \\
\hline $100 \_N$ & 1.060 & 1.076 & 1.051 & 1.062 & 1.130 & 1.089 & 1.045 & 1.088 & 1.146 & 1.061 & 1.025 & 1.077 \\
\hline 200_N & 1.047 & 1.034 & 1.065 & 1.049 & 1.081 & 1.077 & 1.051 & 1.070 & 1.164 & 1.059 & 1.037 & 1.087 \\
\hline o.m. & 1.051 & 1.057 & 1.058 & & 1.104 B & 1.088 B & $1.053 \mathrm{~A}$ & & $1.150 \mathrm{~B}$ & $1.066 \mathrm{~A}$ & $1.033 \mathrm{~A}$ & \\
\hline N_rates & \multicolumn{3}{|c|}{$0.44^{n . s .}$} & & \multicolumn{4}{|c|}{$0.11^{n . s .}$} & \multicolumn{4}{|c|}{$0.58^{n . s .}$} \\
\hline Sh_lev & \multicolumn{4}{|c|}{$0.63^{n . s .}$} & \multicolumn{4}{|c|}{$<0.01 * *$} & \multicolumn{4}{|c|}{$<0.01^{* *}$} \\
\hline N_rates $\times$ Sh_lev & \multicolumn{3}{|c|}{$0.06^{\text {n.s. }}$} & & \multicolumn{4}{|c|}{$0.06^{\text {n.s. }}$} & \multicolumn{4}{|c|}{$0.32^{n . s .}$} \\
\hline
\end{tabular}

${ }^{\mathrm{a}}$ analysis of variance (ANOVA) at $5 \%$ level of probability: $\mathrm{N}$ fertilization rates (N_rates); Sh levels (Sh_lev). o.m.: overall means. ${ }^{*} p<0.05 ;{ }^{* *} p<0.01 ; n . s .=$ not significant. 

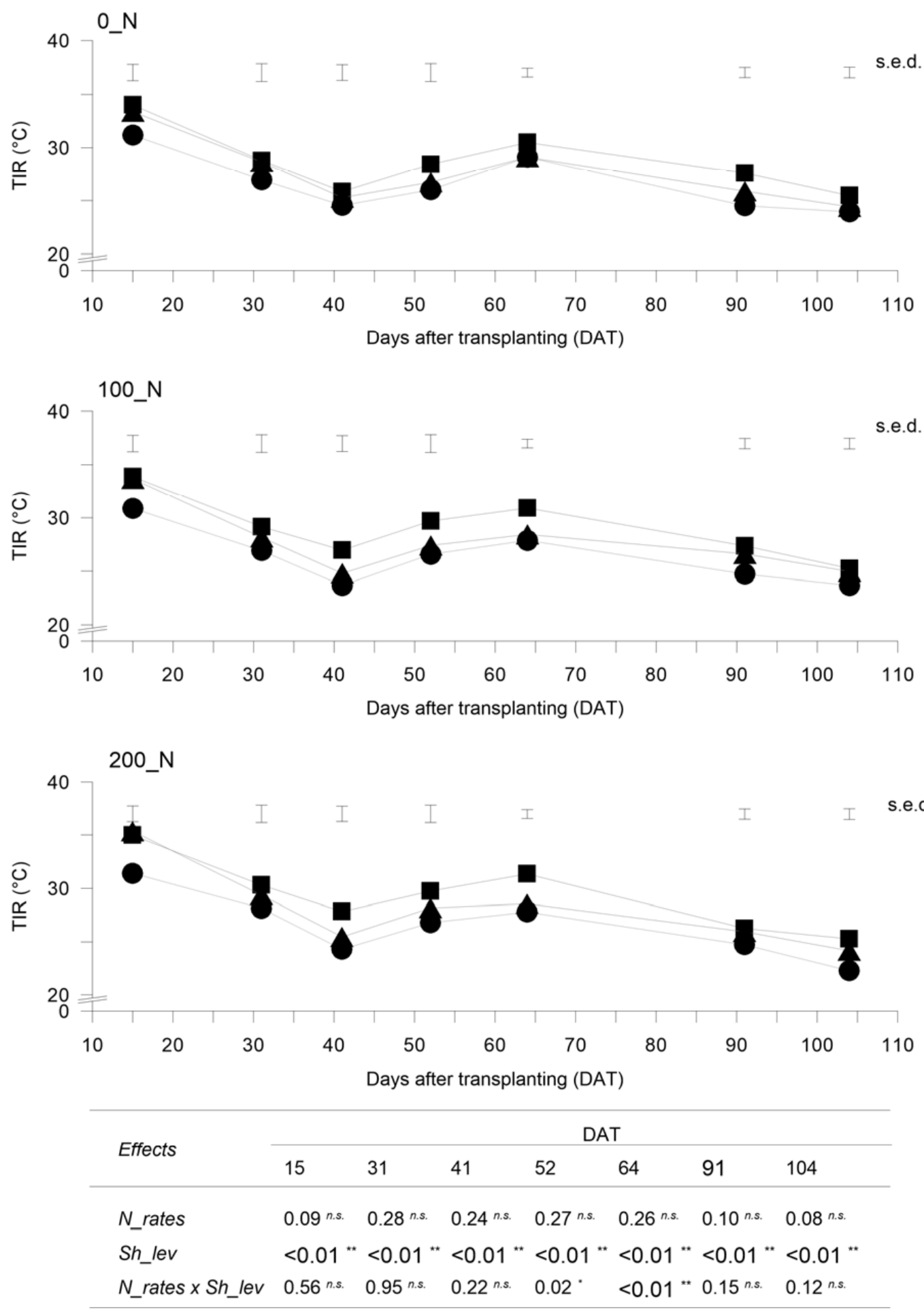

Figure 6. Dynamic of leaf temperature $\left(\mathrm{TIR},{ }^{\circ} \mathrm{C}\right)$ as recorded during the growth cycle of pepper plants subjected to different $\mathrm{N}$ fertilization rates 0_N: $0 \mathrm{~kg} \mathrm{~N}$ ha $^{-1} ; 100 \_\mathrm{N}: 100 \mathrm{~kg} \mathrm{~N} \mathrm{ha}^{-1} ; 200 \_\mathrm{N}: 200 \mathrm{~kg} \mathrm{~N} \mathrm{ha}^{-1}$ ) and shading (Sh) levels (accomplished using: no cover, Control; red photoselective net, RN; black photoselective net, BN), in 2017. Control: black squares; RN: black triangles; BN: black circles. Data are means, over Exp_1 and Exp_2, for $n=6$. In boxes, significance from the analysis of variance (ANOVA) at 5\% level of probability: N rates (Fact_1); Sh levels (Fact_2). At each sampling date, vertical bars represent the standard errors of the difference between means (s.e.d.) for Fact_1 $\times$ Fact_2. ${ }^{*} p<0.05$; ${ }^{* *} p<0.01$; n.s. = not significant. 
Light and $\mathrm{N}$ availabilities affected cuticular wax production in pepper leaves, in the early stages of the crop cycle (i.e., 21 and 42 DAT; Table 7). In particular, the amount of wax per unit leaf area decreased in response to $\mathrm{N}$ fertilization and progressive shading conditions. At 42 DAT, significantly higher values were observed for $0 \_N$ and Control Table 7.

Table 7. Cuticular waxes $\left(\mu \mathrm{g} \mathrm{cm}^{-2}\right)$ as recorded in pepper plants subjected to different $\mathrm{N}$ fertilization rates (0_N: $\left.0 \mathrm{~kg} \mathrm{~N} a^{-1} ; 100 \_\mathrm{N}: 100 \mathrm{~kg} \mathrm{~N} \mathrm{ha}^{-1} ; 200 \_\mathrm{N}: 200 \mathrm{~kg} \mathrm{~N} \mathrm{ha}^{-1}\right)$ and shading (Sh) levels (accomplished using: no cover, Control; red photoselective net, RN; black photoselective net, BN) at 21, 42 and 83 days after transplanting (DAT) in $2017^{\text {a }}$; data are means over Exp_1 and Exp_2. Means followed by different letters (upper case letters: main effects; lower case letters: effects of interaction) significantly differ (Fisher's LSD, $p<0.05$ ).

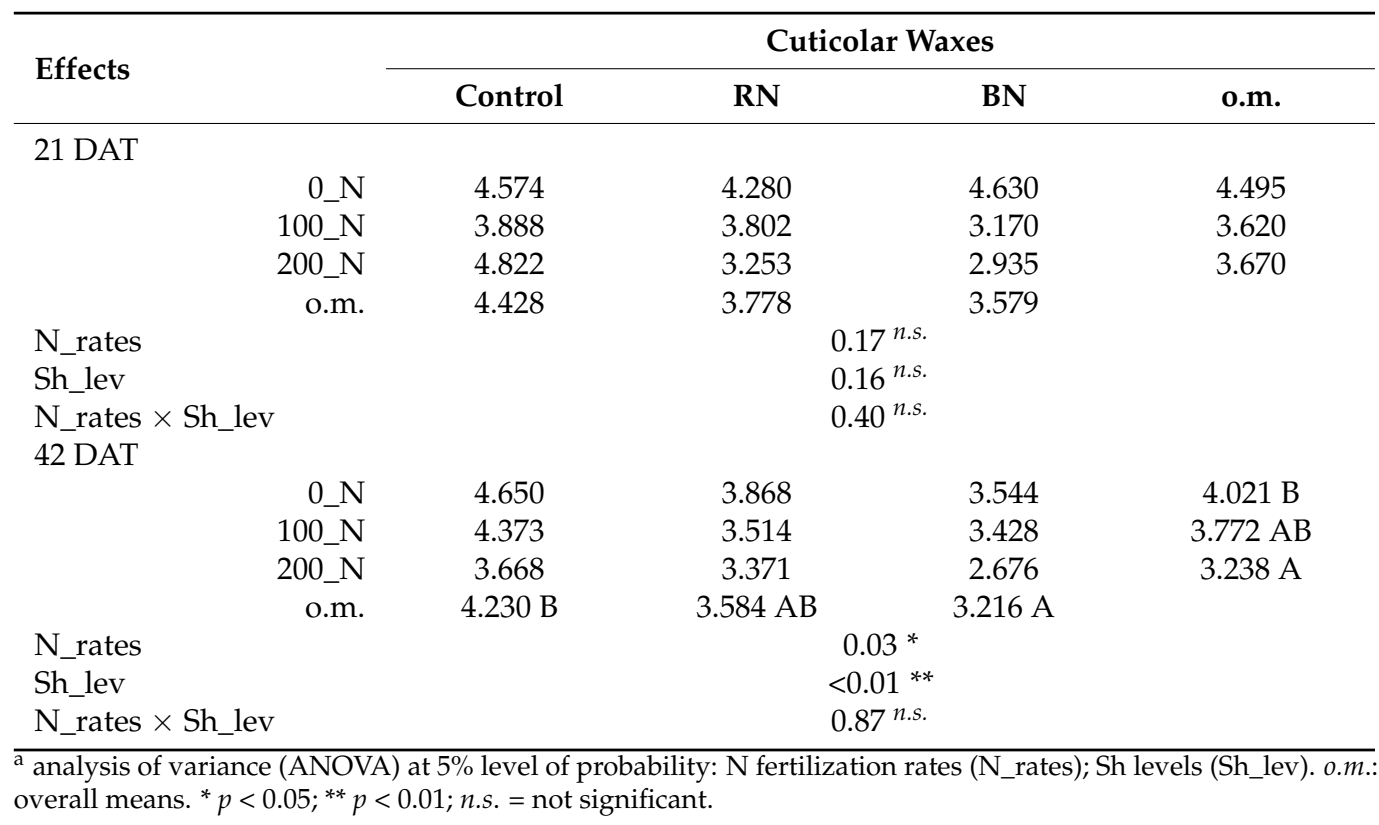

\section{Discussion}

Adaptive responses of plants to the environment are accomplished through a broad range of significant modifications of important growth, morphological and physiological parameters [13].

In this study, the modification of $\mathrm{N}$ and light availability substantially affected the growth and resource allocation patterns of pepper plants. The effects of nitrogen availability on crop growth were clear and $100 \mathrm{~kg} \mathrm{~N} \mathrm{ha}^{-1}$ resulted enough to guarantee good growth performances. Conversely, the influence of photoselective nets on dry biomass was quite undefined. Although the rate of dry mass accumulation is directly related to PAR availability [25], RN application resulted to stimulate biomass production, as already reported in previous studies on other horticultural crops $[6,16,26]$, including sweet pepper [27]. This could be attributed to the mixture of filtered and unfiltered light passing through the red photoselective net [28] and to the higher light scattering (diffuse light) $[6,29]$ than black net, which showed a sharp reduction of transmitted PAR (shading percentage about double than $\mathrm{RN}$ ). In addition, while BN merely induced a reduction of light intensity [30], RN produces a spectral modification, with a significantly lower B:R (blue:red) and B:FR (blue:far red) ratios than Control and BN (B:R ratio: $0.889 \pm 0.001,0.970 \pm 0.006$, and $0.997 \pm 0.002$ for $\mathrm{RN}$, $\mathrm{BN}$, and Control, respectively; B:FR ratio: $1.051 \pm 0.003,1.192 \pm 0.010$, and $1.226 \pm 0.003$ for RN, BN, and Control, respectively).

However, as adaptive responses to the reduction of PAR availability pepper plants of Altino genotype adjusted their morphology and anatomy to capture more light through increasing total and single leaf surface and lowering leaf thickness (higher SLA values), especially at the highest $\mathrm{N}$ dose, as previously observed in other sweet pepper geno- 
types [31-33] as well as horticultural species [25,34-36]. These results confirmed that the role of $\mathrm{N}$ was crucial in stimulating the adaptation responses of the crop under abiotic stress circumstances, allowing pepper plants to build up to longer and larger stems [37]. Furthermore, according to the functional balance hypothesis [38], pepper plants coped with low-light conditions by relocating less assimilates to the sink organs (lower SMR and ReMR), reducing source activity (increasing of both LMR and LAR; [36]) and favouring the building-up of a more expanse and thinner photosynthetic apparatus (higher LA and SLA), characterized by a reduced rate of photosynthesis per unit leaf mass (i.e., low NAR; [39])all shading avoidance mechanisms. Besides, leaf-cuticular wax contents to protect plants from high irradiation levels and UV-light [40], decreased. It can be assumed that the effects registered on leaves could be the same on pepper fruits. Considering the biological roles of cuticular waxes in fruit quality and post-harvest shelf-life-i.e., desiccation control, limiting microbial infection as well as limiting physiological disorders [41,42] — further research activities are needed for this pepper ecotype since the introduction of innovative agronomic techniques aimed at improving post-harvest quality can be justified by both the typicality and the use of the product itself. Indeed, the Altino ecotype is normally subjected to a natural post-harvest drying process, to obtain a sweet pepper powder used in local culinary dishes.

The rusticity and adaptation of the Altino ecotype emerge from our study, especially when the response to low-light and $\mathrm{N}$ availability are combined [43]. Not surprisingly, the effects of moderate shading conditions (i.e., RN) on morphological and growth traits, were amplified by high $\mathrm{N}$ availability (see, for example, LA, SLA, and LAR variables). Under low-N environments, besides a reduction of photosynthetic apparatus-in favour of a probable increase in root accretion [39] - a possible decrease in hydraulic conductance of roots by deficiency of turgor, could inhibit sink organs (i.e., fruits and stems; see also D) development $[44,45]$. Moreover, although no expected significant effect of increased $\mathrm{N}$ input was observed on leaf thickness, important anatomical leaf changes occurred and higher $\mathrm{N}$ availability allowed to less waxy cuticle formation, as previously observed $[46,47]$.

Biomass accumulation and allocation among plant organs can be related to the ratio between total carbon and total nitrogen $(\mathrm{C}: \mathrm{N})$ within plants, and a nearly linear relation between root-to-shoot allocation and internal $\mathrm{N}$ concentration was observed [39]. Reasonable $\mathrm{N}$ fertilizer doses can increase both $\mathrm{N}$ concentrations in pepper aerial apparatus as well as can contribute to improving the nitrogen use efficiency, as extensively observed in other crop species [48]. In our work, shading contributed to compensate for nitrogen accumulation in fruits under $0 \_N$ conditions, thus increasing the radiation use efficiency [49]. However, $\mathrm{N}$ concentration in pepper seemed to be more related to a lower biomass accumulation rather than $\mathrm{N}$ availability [39].

Physiological changes in Altino ecotype leaves regarded mainly some alterations in photosynthetic pigments-including Chla, Chlb, and carotenoids-concentration. N availability stimulated pigment biosynthesis (an indicator of crop nutritional status) [50]. In the same way, the optimization of the photosynthetic rate under light-limiting conditions was also reached by increasing Chl concentrations in leaves [26]. Even Car accumulation, which is involved in the protection of chlorophyll molecules from photooxidation due to excessive solar radiation, followed this trend, confirming the study of Kong et al. [33] on sweet pepper, which demonstrated the influence of photoselective nets on pigments content.

SPAD measurements revealed to be an unreliable indicator for Chl estimation [37]. Besides, other indirect indicators of plant nutritional status and pigment concentration were selected in this work. Based on reflectance data, NDVI, GNDVI, MCARI, and OSAVI, already validated and calibrated at a canopy scale, were selected and calculated [51]. Such indices seemed to effectively detect Sh effects especially in the middle phase of the crop cycle, probably due to the natural leaf senescence later on in the crop cycle, which could reduce any differences.

Noteworthy, some variation of microclimate registered under photoselective nets induced some modification of the crop "water status" which was monitored through WI 
and canopy temperature [8]. In accordance with previous results where lower WI and TIR values corresponded to higher relative water content in plants [36], we observed a general reduction of such parameters under low-light environments. Such results could confirm the higher water use efficiency and the reduced water consumption of pepper genotypes under shading conditions $[52,53]$ and explain the lower total DW reduction exposed by Altino ecotype under shading environments.

\section{Conclusions}

Our study demonstrated that the definition of useful agronomic practices to improve yield and quality of local ecotypes should come from studies on physiological and morphological responses under modified environments. Altino ecotype copes with low light and N availabilities through a series of "factor-specific" changes.

$\mathrm{N}$ availability is determinant to obtain a greater photosynthetic apparatus' efficiency, which in turn results in higher biomass accumulation in all plant organs, including fruits. Altino sweet pepper revealed to have a high $\mathrm{N}$ use efficiency, giving good growth performances already at $100 \mathrm{~kg} \mathrm{~N}^{-1}$, thus limiting the impact of higher $\mathrm{N}$ amount to the environments. Light reduction induces stronger responses, especially when combined with $\mathrm{N}$ rates effects; pepper plants adapted with the typical shading tolerance mechanisms, i.e., a greater expansion of the photosynthetic apparatus at the expense of thinner leaves, as well as a greater concentration of leaf pigments.

Interestingly, leaf cuticular waxes accumulation seems also involved and it should be also evaluated in pepper fruit, to assess the effects of agronomic practices on fruit quality and post-harvest decay.

Further research activities are still required to investigate yield performances as well as fruit quality of Altino ecotype in response to $\mathrm{N}$ and light management, especially in terms of cost-to-benefit analysis in a context characterized by small-scale, niche, and high added-value productions.

It is noteworthy that the to two cycles of phenotypic selection, aimed at characterizing and stabilizing the Altino ecotype for its uniformity, was successful as confirmed by the unsignificant differences emerged between the two selected genotypes utilized for the two experiments.

Supplementary Materials: The following are available online at https:/ /www.mdpi.com/article/10.3 390/agronomy11071343/s1 Figure S1: Plant materials of red sweet pepper Capsicum annuum L., ecotype "Altino", utilized for the "agronomic" experiments in 2017: A, phenotype named as 97; B, phenotype named as 99. The phenotypes were selected based on the keeper farmers' local knowledge, starting from 2015. Table S1: Mainly morphological characteristics of fruits of red sweet pepper, ecotype "Altino": lenght $\left(\mathrm{cm} \mathrm{fruit}^{-1}\right)$, diameter ( $\left.\mathrm{cm}_{\text {fruit }}{ }^{-1}\right)$, and fresh weight $\left(\mathrm{FW}, \mathrm{g}\right.$ fruit $\left.{ }^{-1}\right)$. Means \pm standard errors $(n=100)$ are reported. Phenotypes indicated as 97 and 99 are showed in Figure S1. Figure S2: Layout of a single repetition of the experimental field setted on the Research Centre for Vegetable and Ornamental Crops, Council for Agricultural Research and Economics (CREA-OF), located in Monsampolo del Tronto (AP), Italy, in 2017. Experimental design (split-plot design) consisted of nine sub-plots obtained by splitting the main plots into three areas of equal size. The three $\mathrm{N}$ treatments represented the main plots (0_N: $0 \mathrm{Kg} \mathrm{N}$ ha $^{-1}$; 100_M: $100 \mathrm{~kg} \mathrm{~N} \mathrm{ha}^{-1}$; 200_N: $200 \mathrm{~kg} \mathrm{~N}$ ha $^{-1}$ ); the three shade treatments represented the sub-plots ( $\mathrm{RN}=$ red photo-selective net, depicted as red rectangle; $\mathrm{BN}=$ black photoselective net, depicted as grey rectangle; Control = unshaded; depicted as white rectangle). Green symbols represent pepper plants. This layout was repeated 3 times with a different randomization. Two adjacent experiments were conducted (Exp_1 and Exp_2). Table S2: Principal differences as recorded under red (RN) and black (BN) photoselective nets with respect to unshaded control (Control) in 2017. DQI: irradiance total daily quantum input; PAR: photosynthetically active radiation; DAT: days after transplanting; RH: relative humidity. DQI, \% shading, mean temperatures and RH data are averaged over pepper growing cycle; \% scattering represents the means of 3 independent measurements recorded during crop cycle. 
Author Contributions: Conceptualization, A.G., N.F. and F.S.; methodology, A.G., N.F. and F.S.; formal analysis, C.P. and A.B.; investigation, A.G., C.P. and A.B.; resources, N.F. and G.C.; data curation, A.G. and F.S.; writing —original draft preparation, A.G.; writing—review and editing, A.G., N.F., F.S. and G.C.; supervision, N.F. All authors have read and agreed to the published version of the manuscript.

Funding: This research is a part of the "Programma triennale 2020-2022 per la conservazione, caratterizzazione, uso e valorizzazione delle risorse genetiche vegetali per l'alimentazione e l'agricolturaRecupero, conservazione e valorizzazione di specie orticole, floricole e aromatiche-acronimo RGV/ ORFLORA" -Ente finanziatore: MiPAAF (Ministero delle politiche agricole alimentari e forestali). Processing Charge was covered by "PEPALT", "BLUMEN", "ResAGRARIA", "SAAB-CRA".

Conflicts of Interest: The authors declare no conflict of interest.

\section{References}

1. International Board for Plant Genetic Resources (IBPGR). Genetic Resources of Capsicum; International Board for Plant Genetic Resources: Rome, Italy, 1983.

2. Paran, I.; van der Knaap, E. Genetic and molecular regulation of fruit and plant domestication traits in tomato and pepper. J. Exp. Bot. 2007, 58, 3841-3852. [CrossRef]

3. Fratianni, F.; Cozzolino, A.; d'Acierno, A.; Nazzaro, F.; Riccardi, R.; Spigno, P. Qualitative aspects of some of some traditional landraces of the tomato "Piennolo" (Solanum lycopersicum L.) of the Campania region, southern Italy. Antioxidants 2020, 9, 565. [CrossRef]

4. $\quad$ Lyon, A.; Tracy, W.; Colley, M.; Culbert, P.; Mazourek, M.; Myers, J.; Zystro, J.; Silva, E.M. Adaptability analysis in a participatory variety trial of organic vegetable crops. Renew. Agric. Food Syst. 2020, 35, 296-312. [CrossRef]

5. Rodríguez, A.; Peña-Fleitas, M.T.; Gallardo, M.; de Souza, R.; Padilla, F.M.; Thompson, R.B. Sweet pepper and nitrogen supply in greenhouse production: Critical nitrogen curve, agronomic responses and risk of nitrogen loss. Eur. J. Agron. 2020, 117, 126046. [CrossRef]

6. Ilić, Z.S.; Fallik, E. Light quality manipulation improves vegetable quality at harvest and postharvest: A review. Environ. Exp. Bot. 2017, 139, 79-90. [CrossRef]

7. Mahmood, A.; Hu, Y.; Tanny, J.; Asante, E.A. Effects of shading and insect-proof screens on crop microclimate and production: A review of recent advances. Sci. Hortic. Amst. 2018, 241, 241-251. [CrossRef]

8. Manja, K.; Aoun, M. The use of nets for tree fruit crops and their impact on the production: A review. Sci. Hortic. Amst. 2019, 246, 110-122. [CrossRef]

9. Selahle, K.M.; Sivakumar, D.; Jifon, J.; Soundy, P. Postharvest responses of red and yellow sweet peppers grown under photoselective nets. Food Chem. 2015, 173, 951-956. [CrossRef]

10. Sivakumar, D.; Jifon, J.; Soundy, P. Spectral quality of photo-selective shade nettings improves antioxidants and overall quality in selected fresh produce after postharvest storage. Food Rev. Int. 2018, 34, 290-307. [CrossRef]

11. Do Amarante, C.V.T.; Steffens, C.A.; Argenta, L.C. Yield and fruit quality of 'Gala'and 'Fuji'apple trees protected by white anti-hail net. Sci. Hortic. Amst. 2011, 129, 79-85. [CrossRef]

12. Barker, A.V.; Bryson, G.M. Nitrogen. In Handbook of Plant Nutrition; Barker, A.V., Pilbeam, D.J., Eds.; CRC Press: Boca Raton, FL, USA, 2007; p. 632.

13. Galieni, A.; Stagnari, F.; Speca, S.; Pisante, M. Leaf traits as indicators of limiting growing conditions for lettuce (Lactuca sativa). Ann. Appl. Biol. 2016, 169, 342-356. [CrossRef]

14. Valladares, F.; Niinemets, Ü. Shade tolerance, a key plant feature of complex nature and consequences. Annu. Rev. Ecol. Evol. Syst. 2008, 39, 237-257. [CrossRef]

15. Wang, L.H.; Zhang, B.X.; Daubeze, A.M.; Huang, S.W.; Guo, J.Z.; Mao, S.L.; Palloix, A.; Du, Y.C. Genetics of fertility restoration in cytoplasmic male sterile pepper. Agric. Sci. China 2006, 5, 188-195. [CrossRef]

16. Shahak, Y.; Gal, E.; Offir, Y.; Ben-Yakir, D. Photoselective Shade Netting Integrated with Greenhouse Technologies for improved performance of Vegetable and Ornamental Crops. In Proceedings of the International Workshop on Greenhouse Environmental Control and Crop Production in Semi-Arid Regions, Tucson, AZ, USA, 20-24 October 2008; Volume 797, pp. 75-80.

17. Rouse, J.W.; Haas, R.H.; Schell, J.A.; Deering, D.W. Monitoring vegetation systems in the great plains with ERTS. NASA Special Publ. 1974, 351, 309.

18. Gitelson, A.A.; Kaufman, Y.J.; Merzlyak, M.N. Use of a green channel in remote sensing of global vegetation from EOS-MODIS Remote Sens. Environ. 1996, 58, 289-298.

19. Daughtry, C.S.T.; Walthall, C.L.; Kim, M.S.; De Colstoun, E.B.; McMurtry, J.E. Estimating corn leaf chlorophyll concentration from leaf and canopy reflectance. Remote Sens. Environ. 2000, 74, 229-239. [CrossRef]

20. Rondeaux, G.; Steven, M.; Baret, F. Optimization of soil-adjusted vegetation indices. Remote Sens. Environ. 1996, 55, 95-107. [CrossRef]

21. Peñuelas, J.; Pinol, J.; Ogaya, R.; Filella, I. Estimation of plant water concentration by the reflectance water index WI (R900/R970). Int. J. Remote Sens. 1997, 18, 2869-2875. [CrossRef] 
22. Lichtenthaler, H.K.; Buschmann, C. Extraction of photosynthetic tissues: Chlorophylls and carotenoids. Curr. Protoc. Food Anal. Chem. 2001, 1, F4.2.1-F4.2.6. [CrossRef]

23. Ebercon, A.; Blum, A.; Jordan, W.R. A rapid colorimetric method for epicuticular wax contest of sorghum leaves. Crop Sci. 1977, 17, 179-180. [CrossRef]

24. R Core Team. R: A Language and Environment of Statistical Computing; R Foundation for Statistical Computing: Vienna, Austria, 2017. Available online: https:/ / www.rproject.org (accessed on 1 June 2020).

25. Stagnari, F.; Galieni, A.; Cafiero, G.; Pisante, M. Application of photo-selective films to manipulate wavelength of transmitted radiation and photosynthate composition in red beet (Beta vulgaris var. conditiva Alef.). J. Sci. Food Agric. 2014, 94, 713-720. [CrossRef]

26. Ilić, S.Z.; Milenković, L.; Dimitrijević, A.; Stanojević, L.; Cvetković, D.; Kevrešan, Ž.; Fallik, E.; Mastilović, J. Light modification by color nets improve quality of lettuce from summer production. Sci. Hortic. Amst. 2017, 226, 389-397. [CrossRef]

27. Shahak, Y. Photoselective Netting: An Overview of the Concept, Research and Development and Practical Implementation in Agriculture. In Proceedings of the International CIPA Conference 2012 on Plasticulture for a Green Planet, Tel Aviv, Israel, 15-17 May 2012; Volume 1015, pp. 155-162.

28. Legarrea, S.; Karnieli, A.; Fereres, A.; Weintraub, P.G. Comparison of UV-absorbing nets in pepper crops: Spectral Properties, effects on plants and pest control. Photochem. Photobiol. 2010, 86, 324-330. [CrossRef] [PubMed]

29. Buthelezi, M.N.D.; Soundy, P.; Jifon, J.; Sivakumar, D. Spectral quality of photo-selective nets improves phytochemicals and aroma volatiles in coriander leaves (Coriandrum sativum L.) after postharvest storage. J. Photochem. Photobiol. B 2016, 161, 328-334. [CrossRef]

30. Shahak, Y. Photo-Selective Netting for Improved Performance of Horticultural Crops. A Review of Ornamental and Vegetable Studies Carried Out in Israel. In Proceedings of the XXVII International Horticultural Congress-IHC2006: International Symposium on Cultivation and Utilization of Asian, Nairobi, Kenya, 31 July-3 August 2006; Volume 770, pp. 161-168.

31. Díaz-Pérez, J.C. Bell pepper (Capsicum annum L.) crop as affected by shade level: Microenvironment, plant growth, leaf gas exchange, and leaf mineral nutrient concentration. HortScience 2013, 48, 175-182. [CrossRef]

32. Ilić, Z.S.; Milenković, L.; Šunić, L.; Barać, S.; Mastilović, J.; Kevrešan, Ž.; Fallik, E. Effect of shading by coloured nets on yield and fruit quality of sweet pepper. Zemdirb. Agric. 2017, 104, 53-62. [CrossRef]

33. Kong, Y.; Avraham, L.; Ratner, K.; Shahak, Y. Response of Photosynthetic Parameters of Sweet Pepper Leaves to Light Quality Manipulation by Photoselective Shade Nets. In Proceedings of the VII International Symposium on Light in Horticultural Systems, Wageningem, The Netherlands, 15-18 October 2012; Volume 956, pp. 501-506.

34. Ilić, Z.S.; Milenković, L.; Šunić, L.; Fallik, E. Effect of coloured shade-nets on plant leaf parameters and tomato fruit quality. J. Sci. Food Agric. 2015, 95, 2660-2667. [CrossRef] [PubMed]

35. Stagnari, F.; Galieni, A.; Pisante, M. Shading and nitrogen management affect quality, safety and yield of greenhouse-grown leaf lettuce. Sci. Hortic. 2015, 192, 70-79. [CrossRef]

36. Stagnari, F.; Di Mattia, C.; Galieni, A.; Santarelli, V.; D’Egidio, S.; Pagnani, G.; Pisante, M. Light quantity and quality supplies sharply affect growth, morphological, physiological and quality traits of basil. Ind. Crops Prod. 2018, 122, 277-289. [CrossRef]

37. Díaz-Pérez, J.C.; John, K.S. Bell Pepper (Capsicum annum L.) under colored shade nets: Plant Growth and physiological responses. HortScience 2019, 54, 1795-1801. [CrossRef]

38. Wilson, J.B. A review of evidence on the control of shoot: Root ratio, in relation to models. Ann. Bot. 1998, 61, 433-449. [CrossRef]

39. Grechi, I.P.H.V.; Vivin, P.; Hilbert, G.; Milin, S.; Robert, T.; Gaudillère, J.P. Effect of light and nitrogen supply on internal C: N balance and control of root-to-shoot biomass allocation in grapevine. Environ. Exp. Bot. 2007, 59, 139-149. [CrossRef]

40. Lee, S.B.; Suh, M.C. Advances in the understanding of cuticular waxes in Arabidopsis thaliana and crop species. Plant Cell Rep. 2015, 34, 557-572. [CrossRef]

41. Tafolla-Arellano, J.C.; Báez-Sañudo, R.; Tiznado-Hernández, M.E. The cuticle as a key factor in the quality of horticultural crops. Sci.-Hortic. Amst. 2018, 232, 145-152. [CrossRef]

42. Parsons, E.P.; Popopvsky, S.; Lohrey, G.T.; Alkalai-Tuvia, S.; Perzelan, Y.; Bosland, P.; Bebeli, P.J.; Paran, I.; Fallik, E.; Jenks, M.A. Fruit cuticle lipid composition and water loss in a diverse collection of pepper (Capsicum). Physiol. Plant. 2013, 149, 160-174. [CrossRef]

43. Kanai, S.; Adu-Gymfi, J.; Lei, K.; Ito, J.; Ohkura, K.; Moghaieb, R.E.; Fujita, K. N-deficiency damps out circadian rhythmic changes of stem diameter dynamics in tomato plant. Plant Sci. 2008, 174, 183-191. [CrossRef]

44. Carvajal, M.; Cooke, D.T.; Clarkson, D.T. Responses of wheat plants to nutrient deprivation may involve the regulation of water-channel function. Planta 1996, 199, 372-381. [CrossRef]

45. Clarkson, D.T.; Carvajal, M.; Henzler, T.; Waterhouse, R.N.; Smyth, A.J.; Cooke, D.T.; Steudle, E. Root hydraulic conductance: Diurnal aquaporin expression and the effects of nutrient stress. J. Exp. Bot. 2000, 51, 61-70. [CrossRef]

46. Sun, Y.; Wang, M.; Mur, L.A.J.; Shen, Q.; Guo, S. Unravelling the roles of nitrogen nutrition in plant disease defences. Int. J. Mol. Sci. 2020, 21, 572. [CrossRef]

47. Mrnka, L.; Tokárová, H.; Vosátka, M.; Matějka, P. Interaction of soil filamentous fungi affects needle composition and nutrition of Norway spruce seedlings. Trees 2009, 23, 887-897. [CrossRef]

48. Pan, S.; Liu, H.; Mo, Z.; Patterson, B.; Duan, M.; Tian, H.; Hu, S.; Tang, X. Effects of nitrogen and shading on root morphologies, nutrient accumulation, and photosynthetic parameters in different rice genotypes. Sci. Rep. 2016, 6, 1-14. [CrossRef] 
49. Demotes-Mainard, S.; Jeuffroy, M.H. Effects of nitrogen and radiation on dry matter and nitrogen accumulation in the spike of winter wheat. Field Crops Res. 2004, 87, 221-233. [CrossRef]

50. Wang, Y.; Hu, X.; Jin, G.; Hou, Z.; Ning, J.; Zhang, Z. Rapid prediction of chlorophylls and carotenoids content in tea leaves under different levels of nitrogen application based on hyperspectral imaging. J. Sci. Food Agric. 2019, 99, 1997-2004. [CrossRef] [PubMed]

51. Haboudane, D.; Miller, J.R.; Tremblay, N.; Zarco-Tejada, P.J.; Dextraze, L. Integrated narrow-band vegetation indices for prediction of crop chlorophyll content for application to precision agriculture. Remote Sens. Environ. 2002, 81, 416-426. [CrossRef]

52. Möller, M.; Assouline, S. Effects of a shading screen on microclimate and crop water requirements. Irrig. Sci. 2007, 25, 171-181. [CrossRef]

53. Mahmoud, M.I.; Abuo El-kasem, S.A.A. using colored shade nets and organic mulch to improve microclimate, growth, and yield of yellow sweet pepper. Plant Arch. 2021, 21, 210-223. 